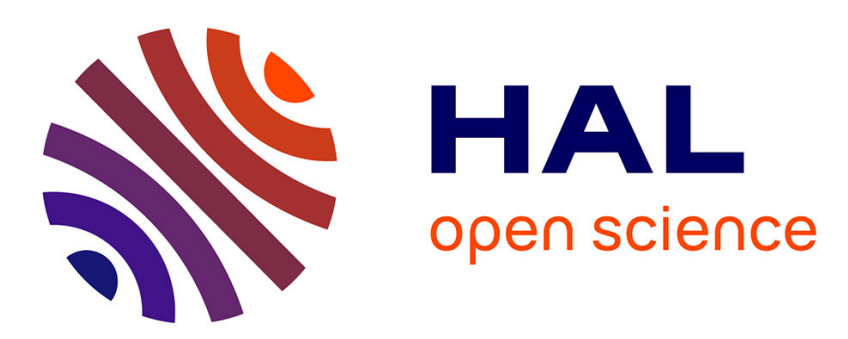

\title{
Physico-chemical stone-mortar compatibility of commercial stone-repair mortars of historic buildings from Paris
}

P. Lopez-Arce, M. Tagnit-Hammou, Beatriz Menendez, J. D. Mertz, M. Guiavarc'h, A. Kaci, S. Aggoun, A. Cousture

\section{To cite this version:}

P. Lopez-Arce, M. Tagnit-Hammou, Beatriz Menendez, J. D. Mertz, M. Guiavarc'h, et al. Physico-chemical stone-mortar compatibility of commercial stone-repair mortars of historic buildings from Paris. Construction and Building Materials, 2016, 124, pp.424-441. 10.1016/j.conbuildmat.2016.07.076 . hal-03266051

\section{HAL Id: hal-03266051 \\ https://hal.science/hal-03266051}

Submitted on 7 Jan 2022

HAL is a multi-disciplinary open access archive for the deposit and dissemination of scientific research documents, whether they are published or not. The documents may come from teaching and research institutions in France or abroad, or from public or private research centers.
L'archive ouverte pluridisciplinaire HAL, est destinée au dépôt et à la diffusion de documents scientifiques de niveau recherche, publiés ou non, émanant des établissements d'enseignement et de recherche français ou étrangers, des laboratoires publics ou privés. 
1 Physico-chemical stone-mortar compatibility of commercial stone-repair mortars

\section{of historic buildings from Paris}

P. Lopez-Arce*1,2, M. Tagnit-Hammou ${ }^{2,3,4}$, B. Menendez ${ }^{2}$, J.D. Mertz ${ }^{3}$, M. Guiavarc'h ${ }^{3}$,

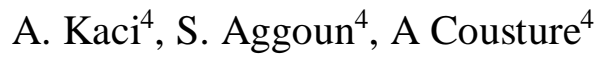

${ }^{1}$ Museo Nacional de Ciencias Naturales (CSIC), C/ Jose Gutierrez Abascal, 2, Madrid, 28024, Spain

${ }^{2}$ Géosciences et Environnement Cergy, GEC, Université de Cergy Pontoise, France

${ }^{3}$ Laboratoire de Recherche des Monuments Historiques (CRC-LRMH USR3224), 29 rue de Paris F-77420 Champs

sur Marne France, France

${ }^{4}$ Laboratoire de Mécanique et Matériaux du Génie Civil, L2MGC, Institut des Matériaux, Université de Cergy Pontoise, F-95000 Cergy Pontoise, France

\section{ABSTRACT}

The physico-chemical compatibility of the most frequently used commercial stonerepair mortars applied to repair surface damage of a common limestone (Euville stone) employed in the basements of historic buildings from Paris was assessed. The characterization of anhydrous raw mortar materials, of stone and mortar samples collected from these buildings and laboratory specimens was carried out.

The presence of chlorides and sulfates (gypsum and mixtures of calcium and sodium sulfates) with minor amounts of nitrates in mortar samples collected from the buildings suggest an origin of salts caused by contamination/pollution coming from past restoration products and environmental pollution. The mortar containing quartz, marble aggregates, portlandite and hydraulic components $\left(\mathrm{C}_{3} \mathrm{~S}, \mathrm{C}_{2} \mathrm{~S}\right.$ and $\left.\mathrm{C}_{2} \mathrm{AS}\right)$ with addition of aluminosilicate micro-spherical particles with cementitious properties, and no phyllosilicates, shows a better chemical compatibility with the stone. The mechanical properties of this mortar are also closer to those of the limestone. However, some differences in the hydric properties due to their different pore systems and aesthetic features should be improved in further restoration works. 
27 Keywords: stone-repair mortars; natural stone; historic buildings; compatibility; physico-chemical properties

\section{Introduction}

From many architectural purposes, mortars can be used as plasters or renders covering the whole surface of walls or building facades, as bedding, jointing or pointing between stone ashlars or bricks, or even they can be used for rebuilding a decayed structure in restoration works. Some kinds of repair mortars can be applied for surface repairs of architectural surfaces. Various terms are used for these specific mortars, stone repair mortar, reconstitution mortar or 'plastic' repair mortar, which have the same or very similar meaning to surface repairs, plastic repairs, surface fills, loss compensation mortars or artificial stone mixtures [1]. During restoration of heritage buildings, mortars are frequently used for the repointing of joints or for the "plastic" repair of stone, which are designed to fill in missing parts of stone. These mortars are moldable mortars that can be applied in situ, and sets into place by its own adhesion to the substrate [2]. From all the possible terms that can be assigned to this kind of mortars, we have chosen 'stone-repair mortar', since it is the clearest name for the purpose of our research, which involve mortars that have been used for repairing or reconstruction of surface damaged stone from restoration works that were carried out in historic buildings. A missing part of an original material is modelled by a new material, which is pliable when applied, and therefore can be adapted into various shapes and finished with required surface textures [1].

Repair mortars used for stone restoration are assumed to be highly compatible with historic materials in terms of physical, chemical and mechanical properties in order to assure the durability of masonry on the long term. A systematic approach for the characterization of historic mortars and materials to be repaired has been defined by 
52 RILEM TC 167 COM which offers a valuable tool to identify mortar components,

53 nature of binder, aggregate, additives, and their relative proportions [3,4]. Ashurst in 541990 [5] described some decision factors on surface repairs, whereas Hughes and Valek 55 in 2003 [6] reviewed the compatibility concept. These mortars must meet a series of 56 requirements from a Cultural Heritage preservation point of view to avoid accelerated 57 deterioration of original material. Material compatibility between repair mortars and the original material suggests that no damage should be caused to the repaired material. For example, the incompatibility among building materials due to the combination of sulfate-bearing mortars and magnesium-rich stone and mortars applied in XVIII restoration works lead to extensive weathering on a historic Monastery (XII century) by magnesium sulfate crystallization processes [7].

63 Nowadays, most professionals turn to commercial pre-mixed mortars. There are many 64 available commercial mortars ready to use in restoration works, from local and 65 international companies. The advantage is that these are prefabricated, and the manufacturer can guarantee that the content's mix is standardized, creating the same workability and properties for each batch, with consistent composition and working properties. This is much appreciated by restoration architects and contractors [8,9]. However, this advantage can be a disadvantage as well. The specially designed mortar 70 for one specific stone can work just for stones with the same or similar physico71 chemical characteristics. Furthermore, in cases where the stone is very heterogeneous, 72 and properties can differ greatly from one stone sample to another, the standardized 73 process will be less successful when aiming to achieve a compatible mortar [10]. 74 Besides, these mixes present an uncertainty about the ingredients they contain. In 75 restoration studies using commercial mortars, aggregates are frequently added to solve 76 the problem of stone heterogeneity [11]. In the case of ready-mixed mortars, powders 
77 can simply be added with the required amount of clean water. However, is important to 78 know the physical properties of the commercial product in order to assure the 79 compatibility with the stone.

80 The selection of a binder is a starting point of the mix design as it predetermines the 81 physical and mechanical properties of the mortar mix, as well as the capacity of the mix

82 to be adapted to the appropriate form and appearance [1]. Natural Hydraulic Lime 83 mortars (NHL) are produced from a naturally occurring 'impure' limestone/chalk. 84 Typically, the impurities are those from clay minerals and other sources of alumina and 85 silica. NHL mortars have been manufactured since the XVIII century by burning these 86 limestones below the clinkering point. These NHL are able to set and harden even under water, as the mechanical strength development is mainly driven by hydration.

88 Carbonation of the slaked lime contributes to the hardening process as well.

89 Hydraulic Limes mortars (HL) are produced by artificially blending calcium hydroxide, 90 calcium silicates and calcium aluminates. This is commonly achieved by blending 91 mixtures of clays and pure limestone, or calcium hydroxide with suitable pozzolanic 92 materials. Pozzolans or pozzolanic materials (fly ash, burnt clays, etc.) are reactive 93 materials that in the presence of soluble calcium hydroxide form hydrated compounds 94 which act as binders. These are often added to increase strength gain in hydrated, 95 hydraulic and natural hydraulic lime based mortars.

96 Greeks and Romans first used hydraulic lime mortars with natural pozzolans in ancient 97 times [12] and Phoenicians employed these binders in Jerusalem (10th century BC) 98 [13]. NHL was used mostly during the nineteenth century. They are nowadays used in 99 restoration of historical buildings because their chemical and physical properties are 100 similar to those of materials used by the original builders, and because they ensure the 101 development of superior mechanical properties, without having the general drawbacks 
102 of Portland cement. NHL was the precursor of Portland cement. The main difference in

103 the production of NHL and cement is the burning temperature. Callebaut et al. in 2001

104 [14] focused on the characterization of nineteenth century hydraulic restoration mortars

105 used in the Saint Michael's Church in Leuven (Belgium), for restoring weathered mortar

106 joints. Based on the presence of a calcium aluminosilicate (gehlenite $\left(C_{2} A S\right)$ ), the

107 dominance of di-calcium silicate (larnite $\left(\mathrm{C}_{2} \mathrm{~S}\right)$ ), the large amounts of portlandite

108 (calcium hydroxide, $\mathrm{CH}$ ), together with chemical analyses and historical sources, these

109 hydraulic mortars were characterized as NHL mortars.

110 The ready-mixed mortars are available as powder materials composed of binders, 111 aggregates and additives already packed together in appropriate ratios. The mortars 112 preparation only consists of simple mixing operations with the correct amount of water 113 (which is usually indicated in the technical data sheets). NHLs are frequently employed 114 as binders in the commercial mixes because of their quick setting capability and 115 remarkable mechanical strengths $[13,15,16]$. The characterization of commercial ready116 mixed mortars, allows verifying their real composition and performance characteristics 117 [17]. However, these composition and properties often differ from those declared in the 118 technical specifications supplied by the manufacturers, finding disagreements with the 119 composition declared by the supplier [18]. There is still a lack for testing the physical 120 properties and durability of mortars according to European standard tests, especially in 121 terms of compatibility with stone, and the long-term behaviour of the repaired 122 mortar/stone interface [11].

123 The aim of this research is to determine the physico-chemical compatibility of the three 124 most frequently used commercial stone-repair mortars applied to repair the surface 125 damage of Euville stone, a common limestone used in the basements of historic 126 buildings in Paris city. 


\section{Materials and methods}

128

131

132 These buildings were repaired in the same period of time corresponding to the

133 restoration campaign 2008-2010. The selected stone is the so-called Euville limestone

134 (Fig.1b) that was used in the outdoor basements of the Grand Palais, Palais de la

135 Découverte and Préfecture de Police historic buildings.

\subsubsection{Stone-repair raw anhydrous mortars}

137 Three commercial mortars, ready to mix with water according to recommendations of 138 the manufacturers, are called in this research Lit, Art and Alt mortars. These are 139 mixtures of natural and hydraulic lime mortars (NHL, HL) with or without aerial lime 140 (CL). Lit mortar (Lithomex Light) is a material produced by Chaux et Enduits St. Astier 141 (CESA, France), based on a St. Astier natural hydraulic lime binder (NHL) and it was 142 used to repair Euville stone at the Grand Palais building (GP). According to the 143 manufacturer, this is a pure NHL, defined as a natural lime, with hydraulic binders, sand 144 and specific additives. According to Torney et al., 2015 [9], Lithomex mortar contains 145 the following components (expressed as percentage of binder): calcium hydroxide 20\%; 146 hydraulic binder (Portland cement) 20\%; filler (vermiculite) 5\%, fine grained quartz and 147 calcite aggregates and talc filler. The technical data sheet of Art mortar (ArtoPierre TM 148 by Parexlanko, France) indicates that this is mainly aerial lime (CL, binder, 70\% in 149 volume) with hydraulic, mineral and organic additives and mineral pigments. 150 Aggregates are mainly calcareous and siliceous with grains up to $1.5 \mathrm{~mm}$. This mortar 151 was used in the Palais de la Découverte building. Finally, Alt mortar (Altar ${ }^{\circledR}$ Pierre by 
152 ECP, France) was used to repair Euville stone in the Préfecture de Police building (PP).

153 According to the manufacturer, quartz grains, calcium carbonate, hydraulic binder,

154 additives and mineral pigments, compose this mortar. The mineralogical and chemical

155 composition of the three mortars, before mixing with water (anhydrous raw materials),

156 was initially determined in this research. Then, the mineralogy and hydric and

157 mechanical properties of hardened single mortar specimens $(4 \times 4 \times 16 \mathrm{~cm})$ were studied

158 after 28 curing (Fig.1c).

159 2.1.2. Stone

160 Euville limestone (Oxfordian, Late Jurassic) is a crinoïdal grainstone almost completely 161 composed of calcium carbonate (98\%) with a coarse-grained texture and a syntaxial 162 cement of calcite. The fabric was formed by an accumulation of coarse crinoïdal 163 ossicles in submarine dunes. Accessory bivalves and spines of sea urchins are also part 164 of the fossil fauna. The outcrops of this limestone are situated near Commercy 165 (Département de la Meuse, France). The Euville limestone is a famous building stone in 166 France, and also in Belgium, where it is often used in combination with Savonnières 167 limestone and Lede stone, and it has often been used as a replacement stone in many 168 historic buildings in several countries in the world

$169[19,20]$. As a restoration measure, some surface areas built with this stone affected by 170 salt crystallization processes have been repaired with several stone-repair commercial 171 mortars. The stone specimens used in this work were supplied by ROCAMAT quarry in 172 Euville, France. The specimens where cut parallel to the bedding with dimensions $1734 \times 4 \times 16 \mathrm{~cm}$ to perform all the hydric and mechanical tests. For the water vapour 174 permeability test cylindrical specimens $1 \mathrm{~cm}$ thick and $4 \mathrm{~cm}$ diameter were prepared. 
178 Three historic buildings from Paris city where the three types of mortars were used to 179 restore Euville stone were selected in order to collect stone and mortar samples. Two 180 small mortar samples were collected, from the Gran Palais building (GP) where 181 Lithomex mortar was used, sample Lit-GP (Fig.2a), and Préfecture de Police building 182 (PP) where Altar Pierre mortar was applied to repair the stone, sample Alt-PP (Fig.2b). 183 At the Préfecture de Police building, a small flake sample of Euville stone (Eu-GP) was 184 also collected from one area with salt crystallization decay that showed efflorescences 185 on the surface of the stone (Fig.2c). It was not possible to collect samples at the Palais 186 de la Découverte building, since the studied area corresponded to a delicate sculpted stone restored with Artopierre stone-repair mortar displaying an apparent good state of conservation.

\subsubsection{Hardened mortar specimens manufactured in the laboratory}

190 The water:powder mortar ratios were prepared in the lab, following as much as possible

191 the recommendations of the manufacturers according to their respective technical data 192 sheets. The manufacturer's preparation guidelines of Lithomex mortar state that the 193 materials should be mixed (mechanically or by hand) for between three and five 194 minutes, with water content of 4.5-5.5 L of water per $25 \mathrm{~kg}$ of dry material. We used 5 $195 \mathrm{~L}$ of water (W) per $25 \mathrm{~kg}$ of dry material (M), i.e. $\mathrm{W}: \mathrm{M}=0.20$. In this case, the restorer 196 who used this type of mortar in the Grand Palais historical building recommended us to 197 add a handful of sand to the mixture. Since the amount of aggregate fraction between 1981.25 and $0.63 \mathrm{~mm}$ in this mortar was much lower compared to the other mortars, 199 according to this information, to grain size distribution analyses and in order to obtain a 200 mortar as similar as possible to the others, $150 \mathrm{~g}$ of normalized sand (fraction 1.25-0.63 201 mm from Ultibat, EN 12620: $2002+$ A1: 2008 [21]), was added to 2000g of raw 
202 anhydrous mortar. To prepare Artopierre mortar, between 6 and $7 \mathrm{~L}$ of water per $30 \mathrm{~kg}$

203 of dry material is required according to the technical data sheet. We used $6.5 \mathrm{~L}$ per 30

$204 \mathrm{~kg}$ of raw anhydrous mortar powder $(\mathrm{W}: \mathrm{M}=0.22)$. To manufacture Altar® Pierre

205 mortar, from 4 up to 6 volume of dry material per 1 volume of water was recommended.

206 To prepare the specimens we used 5 volume of dry material per 1 volume of water

207 (W:M=0.13).

208 A mechanical mixture was performed in the three mortars using an industrial mixer 209 (Controlab, France) during 4 minutes, starting at low speed rotation (62 rpm) during 1 210 min and finishing at high speed (125 rpm). Then, a jolting apparatus was also used 211 according to the standard test UNE-EN 196-1:2006 [22], applying 25 blows to 212 homogenize the mixture and avoiding the formation of air bubbles.

213 Eighteen mortar specimens were prepared, six with each type of mortar, two specimens 214 for the compression-flexural test, two for water absorption under vacuum test and two 215 for capillary-desorption test. These were prepared by molding the mixtures in rubber 216 molds $(4 \times 4 \times 16 \mathrm{~cm})$. Besides, to carry out water vapor permeability tests, plastic moulds 217 filled with each mortar mixture were used. These were big enough to prepare by cutting 218 at least two circular mortar specimens (50 mm diameter x $10 \mathrm{~mm}$ thickness) for each 219 type of mortar. All the specimens were demolded after two days of curing according to 220 the standard test NF-EN 1015-11 [23].

221 For hardening the mortar specimens (28 days curing) we tried to simulate the average 222 annual weather conditions of Paris. The specimens were placed in a ventilated climatic 223 chamber with $\mathrm{CO}_{2}$ uptake from the environment (400 ppm approx.) at $11^{\circ} \mathrm{C}$ and $85 \%$ 224 relative humidity $(\mathrm{RH})$ ) during 7 days. Then, $\mathrm{RH}$ was changed down to $65 \%$ during the 225 next 7 days, followed by laboratory conditions in a climatic room at $20^{\circ} \mathrm{C}$ and $50 \% \mathrm{RH}$ 226 during 14 days, under environmental $\mathrm{CO}_{2}$ (400 ppm approx.)). The reason why $\mathrm{RH}$ was 
227 reduced from $85 \%$ down to $65 \%$ during the $7-14$ curing days was first of all, because

228 the average annual RH in Paris city was in the range 65-85\% RH approx. In a second

229 place because these commercial mortars are mixtures of hydraulic and aerial lime.

230 According to the literature [24,25], a high and a lower $\mathrm{RH}$, respectively, is

231 recommended to set up suitable curing conditions. The European standard AFNOR EN

232 1015-11 [23] defines the following optimal conditions of temperature and relative

233 humidity for the curing of mortar samples in the laboratory at $\mathrm{T}=20 \pm 2{ }^{\circ} \mathrm{C}$ and

$234 \mathrm{RH}=95 \pm 5 \%$ for the first 5 days in the mold, the following 2 days removed from the

235 mold, and at $\mathrm{T}=20 \pm 2{ }^{\circ} \mathrm{C}$ and $\mathrm{RH}=65 \pm 5 \%$ for the following 21 days. So, $85-65 \% \mathrm{RH}$

236 and $11^{\circ} \mathrm{C} \mathrm{T}$ conditions were selected the first 14 days in order to simulate as much as

237 possible the environmental curing conditions of Paris and at the same time trying to

238 perform a laboratory test in a gradual way choosing the most suitable as possible curing

239 conditions for these type of mortars. The environmental conditions of the final 14 days

240 to reach 28 curing days had to be performed at $\mathrm{RH} 50 \pm 5 \%, \mathrm{~T} 20^{\circ} \mathrm{C}$ in a climatic room

241 only due to availability and space reasons.

242 2.2. Analytical techniques and experimental test methods

\section{2.2.1. Mineralogical and chemical analyses}

244 Polarizing optical microscopy was used to study the main mineralogical constituents

245 and textures of the mortar samples collected from the buildings and the hardened single

246 mortar specimens after 28 days curing. The samples were impregnated with epoxy resin

247 mixed with blue dye to fill the porosity in order to be easily recognized under the

248 microscope with parallel nicols. The thin sections were studied with an Olympus BX50

249 polarized light microscope fitted with an Olympus digital camera.

250 X-ray diffraction (XRD) was used to determine the mineralogical composition of raw

251 anhydrous mortar samples, hardened single mortar specimens manufactured with them 
252 after 28 days curing and samples collected from the buildings. Furthermore, soluble

253 fractions prepared to carry out ion chromatography analyses were left to evaporate and

254 the product was also analysed by XRD. The analyses were conducted on a Bruker D8

255 Advance diffractometer with $\mathrm{CoK} \alpha$ radiation powder. The scanning conditions were $2 \theta$

256 angles of $5-65^{\circ}$, scan step size $0.05^{\circ}$, time step $1 \%$ in continuous mode, and beam

257 intensity of $40 \mathrm{kV}$ and $35 \mathrm{~mA}$. The diffractometer worked with a CoK $\alpha$ radiation,

258 instead of the most common used $\mathrm{CuK \alpha}$ and so there is a slight variation in the grades

259 of the $2 \theta$ peaks used to identify minerals. The identification of the mineral phases was

260 performed using the Bruker AXS DiffracPlus EVA software also used to carry out

261 semi-quantitative analyses.

262 Scanning electron microscopy (SEM) coupled with Energy dispersive X-ray 263 spectroscopy (EDS), was used to find weathering products caused by decay processes 264 and to identify the type of salt efflorescences and sub-efflorescences on the top and 265 underneath (some millimetres depth) the surface of stone and mortar fragments 266 collected from the buildings. A SEM microscope Leica S430i was used. The elemental 267 composition of some selected components from these building samples together with 268 the raw anhydrous mortar samples was determined by means of EDS semi-quantitative 269 microanalyses by means of an Bruker micro-analyser spectrometer. Nickel-sputtered 270 fragments from the samples were studied in secondary electrons mode.

271 In order to perform the chemical composition by EDS analyses of each grain size 272 fraction of the raw anhydrous mortars (aggregates and binder), the grain or particle size 273 distribution was carried out by sieving $200 \mathrm{~g}$ approx. of each mortar according to the 274 standard test AFNOR NF-EN 1015-1 [26]. The sieve sizes that have been used are the 275 following: $1.60 \mathrm{~mm}, 1.25 \mathrm{~mm}, 0.63 \mathrm{~mm}, 0.315 \mathrm{~mm}, 0.20 \mathrm{~mm}, 0.16 \mathrm{~mm}, 0.080 \mathrm{~mm}$ and $2760.080 \mathrm{~mm}$. Then, the largest sizes $(1.60-1.25 \mathrm{~mm}$ and $1.25-0.63 \mathrm{~mm})$ were impregnated 
277 in epoxy resin and then polished, in order to study their shape and chemical 278 composition by SEM-EDS analyses. Each grain size range of the finest fractions (from 2790.63 down to below $0.080 \mathrm{~mm}$ ) was pressed in small tablets and then analyzed by EDS 280 previously sputtering the samples with nickel (Ni).

281 Ion chromatography (IC) analysis was performed to quantify the soluble salts present in 282 the raw anhydrous mortars and samples collected from the buildings. Some anions $\left(\mathrm{Cl}^{-}\right.$, $283 \mathrm{NO}^{-3}, \mathrm{PO}_{4}{ }^{2-}$ and $\left.\mathrm{SO}_{4}{ }^{2-}\right)$ and cations $\left(\mathrm{Na}^{+}, \mathrm{K}^{+}, \mathrm{Mg}^{2+}, \mathrm{Ca}^{2+}\right.$ and $\left.\mathrm{NH}_{4}{ }^{+}\right)$were determined. 284 Approximately $0.1 \mathrm{~g}$ of sample was dissolved in $10 \mathrm{ml}$ of Milli-Q ultrapure water and 285 placed it for $5 \mathrm{~min}$ in an ultrasonic bath at room temperature. The solution with the solid 286 residue was then left to settle down with a minimum rest period of $24 \mathrm{~h}$. The soluble 287 salts of raw materials and samples collected from the buildings were quantified on a 288 Dionex DX-120 ion chromatograph.

\subsubsection{Physical tests}

290 To determine hydric and mechanical properties, together with physical characteristics 291 such as density, porosity and color parameters, the following tests were carried out in 292 the stone and mortar specimens.

293 Water absorption by capillarity was carried out to evaluate the liquid water transfer into 294 the materials. The capillary coefficients were calculated for the Euville stone and 295 hardened single mortar specimens. The standard test AFNOR NF EN 1925:1999 [27] 296 was followed; the results are expressed in $\mathrm{g} /\left(\mathrm{m}^{2} \cdot \mathrm{s}^{1 / 2}\right)$ instead of $\mathrm{kg} /\left(\mathrm{m}^{2} \cdot \mathrm{s}^{1 / 2}\right)$. Once 297 capillarity saturation was reached, the specimens were spun to ease the water drying 298 under laboratory conditions $\left(45 \pm 5 \% \mathrm{RH}\right.$ and $\left.20 \pm 1^{\circ} \mathrm{C}\right)$ and to calculate desorption 299 coefficient (water loss or evaporation) weighing the specimens at several intervals of 300 time. 
301 Water vapour permeability test was carried out in the stone and mortar specimens. The 302 standard test AFNOR EN 15803:2010 [28], with wet cup was followed to calculate the 303 water vapor permeability $\left(\mathrm{Kg} /\left(\mathrm{m}^{2} \mathrm{~s}\right)\right)$. External relative humidity of $50 \%$ and 304 temperature of $23^{\circ} \mathrm{C}$ were achieved introducing the specimens in a climatic chamber, 305 setting these conditions during all the duration of the test.

306 Water absorption under vacuum was performed in the stone and hardened mortar 307 specimens, to determine differences on apparent density $\left(\mathrm{kg} / \mathrm{m}^{3}\right)$, bulk density $\left(\mathrm{kg} / \mathrm{m}^{3}\right)$, 308 and to calculate open porosity (\%) as described in standard test AFNOR EN 1936:2007 309 [29].

310 Flexural strength measurements were carried out in the stone and hardened mortar 311 specimens, with a maximum load of $8 \mathrm{kN}$ and load rate of $0.05 \mathrm{kN} / \mathrm{S}$. Compression 312 strength measurements were performed in the four fragments obtained from the 313 breaking of two specimens after the flexural test. A maximum load of $250 \mathrm{kN}$ and load 314 rate of $2.4 \mathrm{kN} / \mathrm{S}$ was applied until breaking, providing values equal or above $7 \mathrm{MPa}$, 315 since this is the minimum value detected by the compression cell. A Quantech 3R press 316 (Quantium $^{\mathrm{TM}}$, Researchers \& Realisations, France) that follows the standard test 317 AFNOR EN196-1:2006 [30] was used.

318 Total Hg-porosity and pore size distribution analysis was carried out by mercury 319 intrusion porosimetry in the stone and mortar samples collected from the building and 320 the superficial part of hardened mortar specimens manufactured in the laboratory. 321 Readings were taken at pore radius of $0.003-200 \mu \mathrm{m}$ under measuring conditions 322 ranging from atmospheric pressure to $228 \mathrm{MPa}$ on a Micromeritics Autopore IV 9500.

323 Color parameters were measured on the stone and mortar hardened specimens. L* 324 parameter, which accounts for luminosity, hue and saturation (chroma, C), a* and $b^{*}$ 325 coordinates ( $\mathrm{a}^{*}$ being the red-green parameter and $\mathrm{b}^{*}$ the blue-yellow) were obtained. 
326 Total color difference $\Delta \mathrm{E}^{*}$ was provided as a result of the formula $\Delta \mathrm{E}^{*}=\left(\left(\Delta \mathrm{L}^{*}\right)^{2}+\right.$

$\left.327\left(\Delta \mathrm{a}^{*}\right)^{2}+\left(\Delta \mathrm{b}^{*}\right)^{2}\right)^{1 / 2}$. Measurements were performed with a spectrophotometer Konica 328 MINOLTA CM-2300d using the CieLab color space; standard illuminant was D65 and 329 observer angle, $10^{\circ}$.

\section{3. Results}

\subsection{Characterization of raw anhydrous mortars}

332 The main mineralogical composition of Lit mortar determined by XRD is calcite, 333 quartz, feldspar and phyllosilicates (clinochlore and talc), followed by hydraulic 334 components, larnite (i.e. $\mathrm{C}_{2} \mathrm{~S}$ or belite), alite $\left(\mathrm{C}_{3} \mathrm{~S}\right)$ and traces of gehlenite $\left(\mathrm{C}_{2} \mathrm{AS}\right)$. Art 335 mortar contains mainly quartz, calcite and portlandite (i.e. $\mathrm{CH}$ or $\mathrm{Ca}(\mathrm{OH})_{2}$ ) and 336 hydraulic phases, di-calcium silicate (larnite) and tri-calcium silicate (alite), and traces 337 of feldspar and calcium-aluminium silicate (gehlenite). A small hump between 10 and $33815^{\circ} 2 \theta$ can be observed in the XRD pattern of this mortar, which might be related to the 339 presence of clays. Alt mortar XRD pattern shows quartz, feldspar, calcite, portlandite, 340 larnite, alite and traces of gypsum and gehlenite (Fig.3 and Table 1).

341 The SEM-EDS analyses performed in several areas of mineral grains (aggregates) with 342 sizes between 1.6-1.25 mm and $1.25 \mathrm{~mm}-0.63 \mathrm{~mm}$ of Lit mortar (Fig. 4a) correspond to 343 phyllosilicates compositions (clinochlore and talc), with and without additional $\mathrm{K}, \mathrm{Ti}$ 344 and $\mathrm{Cl}$ only detected in the aggregates in the range between $1.6-1.25 \mathrm{~mm}$ (Table 2). 345 Mineral grains of Lit mortar with sizes in the range between 1.25-0.63 mm correspond 346 to calcite composition with some traces of $\mathrm{Mg}, \mathrm{Al}, \mathrm{Si}$ and $\mathrm{Na}$ (Fig. 4b). The results of 347 these analyses performed in Art mortar show that the mineral grains in the ranges 348 between $1.6-1.25 \mathrm{~mm}$ and $1.25 \mathrm{~mm}-0.63 \mathrm{~mm}$ are mainly, calcite, quartz (that were 349 deposited in the bottom of the prepared epoxy specimen) and similar phyllosilicates 350 than those present in Lit mortar (Fig.4c). By contrast, SEM-EDS analyses carried out in 
351 the grain sizes between $1.60-1.25 \mathrm{~mm}$ and $1.25-0.63 \mathrm{~mm}$ of Alt mortar show that these

352 are only composed by sub-rounded and sharp calcite composition grains, which

353 partially might correspond to the marble grains added by the manufacturer (Fig.4d).

354 Some of these grains contain some fissures filled with quartz and some impurities such

355 as sodium chloride $(\mathrm{NaCl})$. The composition of these largest grain size aggregates in

356 this latter mortar shows significant differences compared to the other two mortars

357 (Table 2), since $\mathrm{Al}, \mathrm{Mg}$ and $\mathrm{k}$ are not detected and there is no $\mathrm{Fe}$ and $\mathrm{Ti}$ in the fraction 358 between $1.60-1.25 \mathrm{~mm}$.

359 In the three mortars, the composition of the aggregates between 0.63 and $0.20 \mathrm{~mm}$ is 360 mainly siliceous ( $\mathrm{Si}$ content between 20 and $40 \mathrm{wt}$ \% approx.), and this is especially 361 marked in Alt mortar (Table 3). Below $0.20 \mathrm{~mm}$ the Si content greatly decreases at 362 expenses of $\mathrm{Ca}$ content, which especially increase in Art and Alt mortars (between 27 363 and 40 wt. \% approx.). Besides this, the main difference among the three mortars is the 364 Na content in Alt mortar which increases with the decrease of grain size (except in the 365 range between 0.16 and $0.080 \mathrm{~mm}$ ), from 4 wt. \% (between $0.63-0.315 \mathrm{~mm}$ ) up to 33 wt. \% (below $0.080 \mathrm{~mm}$ ).

367 Ion chromatography analyses show that none of the anhydrous mortars display nitrates 368 in their composition (Table 4). However, the three have a slight amount of chlorides 369 (circa $5 \mathrm{ppm}$ ). The only one displaying soluble sulfates is Lit mortar (23 ppm approx.). 370 The concentration in bulk material (wt.\%) of the identified total soluble salts (cations 371 and anions) represents very low percentages in Lit and Alt mortars (2\%) and slightly 372 higher values in Art mortar (circa $5 \%$ ). There is a high amount of soluble $\mathrm{Ca}^{2+}$ in the 373 three mortars and this is especially high in Art mortar. No nitrates or phosphates, neither 374 ammonium have been detected in these samples. 
377 Petrography of mortars thin sections performed under optical light microscopy shows 378 that Lit mortar from the Grand Palais building has a large quantity of rounded esparitic 379 calcite and quartz grains with submillimetric sizes, together with some micas and many 380 phyllosilicates embedded in a scarce micritic matrix composed by a mixture of calcite 381 and clays. The ratio binder:aggregate is approximately 1:4 (Fig. 5a and 5b). Feldspar 382 grains show up with a high degree of cracking at the surface of the mortar that was in 383 contact with the surrounded environment where the sample was collected. Porosity is 384 mainly fissural and surrounds the mineral grains and goes through the clay minerals and 385 through the matrix. Large pores inside the matrix are associated in some areas to the 386 phyllosilicates showing signs of weathering (Fig.5c and 5d). Thin sections of Alt mortar 387 from Préfecture de Police building also show a high amount of calcite crystals inside 388 sharp fragments of fossiliferous micritic and esparitic limestone rocks, bioclasts and 389 marble fragments of millimetric size. Abundant smaller feldspar and subhedral quartz 390 grains with cement as syntaxial overgrowths are also embedded in a dense dark matrix.

391 The ratio binder:aggregate is approximately 1:3 (Fig.5e and 5f). Small rounded (circa $39250 \mu \mathrm{m}$ ) and larger sub-rounded pores (between 200 and $400 \mu \mathrm{m}$ ), together with small spherical particles (circa $50 \mu \mathrm{m})$ are present inside this matrix. Some of these particles seem to be stuffed with an amorphous gel, being difficult to distinguish them from the matrix, while many others are empty and filled now with the dyed blue resin used to 396 mark the porosity of the mortar samples (Fig.5g and 5h).

397 The XRD pattern of Lit mortar collected from the Grand Palais building (Lit-GP), 398 displays the same mineralogy than the obtained in the raw anhydrous mortar, with the 399 exception of the presence of muscovite $\left(\mathrm{K}(\mathrm{Li}, \mathrm{Al})_{2}\left(\mathrm{Si}_{3} \mathrm{AlO}_{10}\right)(\mathrm{OH})_{2}\right)$ and gypsum $400\left(\mathrm{CaSO}_{4} \cdot 2 \mathrm{H}_{2} \mathrm{O}\right)$ and the absence of larnite $\left(\mathrm{C}_{2} \mathrm{~S}\right)$ and alite $\left(\mathrm{C}_{3} \mathrm{~S}\right)$ (Fig.6). The semi- 
401 quantitative (\%) analyses show different concentrations in all the identified phases

402 compared to its corresponding raw material (Table 1). The mineralogy of the salts 403 precipitated from the soluble fraction of Lit mortar prepared to carry out the ion

404 chromatography analyses, that were left to evaporate (Lit-GP-sf), shows an increase of 405 gypsum peaks and the appearance of halite $(\mathrm{NaCl})$. Some residues of non-soluble 406 fraction (quartz, calcite, clinochlore and talc) are also detected.

407 The XRD pattern of Alt mortar collected from the Préfecture de Police building (Alt408 PP) also shows the same mineralogy than the obtained in the anhydrous raw material, 409 with the exception of no detection of gypsum, the absence of alite $\left(\mathrm{C}_{3} \mathrm{~S}\right)$ and the 410 presence of a minor amount of larnite $\left(\mathrm{C}_{2} \mathrm{~S}\right)$. The semi-quantitative $(\%)$ analyses also 411 show different concentrations in all the identified phases compared to its corresponding 412 raw material, especially in the amount of portlandite (Fig.6). No salts are identified in 413 the mortar sample collected from this building and neither in the precipitated soluble 414 fraction. The XRD of Euville stone flake (soluble fraction after evaporation) shows 415 gypsum, halite and traces potassium-sodium sulfate.

416 The SEM-EDS analyses of the surface of Lit mortar from the Gran Palais, mainly shows $417 \mathrm{Ca}, \mathrm{Mg}, \mathrm{C}, \mathrm{O}, \mathrm{Si}$ and $\mathrm{Al}$ as the main components present in all the analyzed zones. 418 Underneath the surface it shows aggregates of quartz and mainly $\mathrm{Si}$ and $\mathrm{Ca}$ (i.e. calcium 419 silicates) as the composition of the binder. There are zones with large amounts of salts 420 composed by $\mathrm{S}$ and $\mathrm{Ca}$ (i.e. gypsum) and $\mathrm{Na}$ and $\mathrm{Cl}$ (i.e. sodium chloride) (Fig.7a, zone 4211 and zone 2, respectively). A great number of phyllosilicates is also observed.

422 On the surface of Alt mortar samples from Préfecture de Police building, Si, Ca, Al, C, $423 \mathrm{O}, \mathrm{Na}$ and $\mathrm{Cl}$ are the main components, with variable amounts in all the analyzed zones. 424 There are zones with large amounts of $\mathrm{Na}$ and $\mathrm{Cl}$ (sodium chloride). Underneath the 425 surface of Alt mortar, the main composition of the binder is $\mathrm{Si}$ and $\mathrm{Ca}$, with $\mathrm{Al}, \mathrm{C}$ and 
426 O. Many micron-size spherical particles can be observed, some of them seem to be 427 cracked and empty and others seem to be filled with a "viscous" phase. The EDS 428 analyses show a thin external part mainly composed by aluminosilicates (Fig.7b, zone 429 1), which might correspond to mullite $\left(2 \mathrm{Al}_{2} \mathrm{O}_{3} \cdot \mathrm{SiO}_{2}\right)$. Some of them display also $\mathrm{Ca}$ in 430 the external part. The analyses of the interior part of these particles show a high increase 431 in $\mathrm{Ca}$ and minor amounts of $\mathrm{Na}$ and $\mathrm{Mg}$ (Fig. 7b, zone 2). Aggregates of marble 432 fragments can also be observed. However, they display low amount of $\mathrm{C}$ and some $\mathrm{Al}$ in 433 their composition. The EDS analyses of Alt mortar (external and internal parts) indicate 434 the presence of salts (sodium chloride) together with aluminosilicates, calcium silicates, 435 calcium aluminosilicates, calcium carbonate and silicon oxides.

436 The surface of Euville stone flake displays salt efflorescences containing $\mathrm{S}, \mathrm{K}, \mathrm{Ca}$ and $437 \mathrm{Na}$ (Fig.7c, surface zone). Some millimeters depth from the surface, the SEM images 438 show sub-efflorescences of sodium and calcium sulfate crystals mixed together, which 439 might corresponds to thenardite and gypsum, respectively (Fig. 7c, interior zone).

440 Table 5 shows the ion chromatography results of soluble salts present in the samples 441 collected from the buildings. There is a large amount of sulfates in Lit mortar sample 442 collected from Grand Palais, above $100 \mathrm{ppm}$. The amount of sulfates in Alt mortar 443 sample from Préfecture de Police is much lower (21 ppm). The amount of chlorides is 444 also lower in Alt mortar (11 ppm) compared to Lit mortar (circa $30 \mathrm{ppm}$ ). The presence 445 of nitrates is detected in both mortars, circa $25 \mathrm{ppm}$ in Lit mortar and circa $34 \mathrm{ppm}$ in 446 Alt mortar. The concentration in bulk material (wt.\%) indicates higher percentages of 447 total soluble salts (cations and anions) in Lit mortar compared to Alt mortar, even 448 though these values are very small in both cases. The ion chromatography analyses of 449 the stone flake collected from the Préfecture Police building show a concentration of 450 sulfates and chlorides of $984 \mathrm{ppm}$ and $17 \mathrm{ppm}$, respectively. Nitrates were not detected 
451 in this sample. The content of soluble $\mathrm{K}^{+}$and $\mathrm{Ca}^{2+}$ in this sample is especially high. The

452 concentration of salts in bulk material in this sample (that contained efflorescences) is 453 much higher compared to the mortars (circa $12 \mathrm{wt} . \%$ ). No phosphates or ammonium

454 were detected in these samples.

455 Figure 8 shows the pore size distribution obtained by mercury intrusion porosimetry in 456 the mortars collected from the buildings, which have a very different total porosity 457 accessible to mercury. Lit mortar sample has a higher total Hg-porosity (circa 26\%) 458 compared to Alt mortar (circa 16\%). The pore size distribution of the former is mainly 459 polymodal with the highest volume of pores with radius in the range between $0.1 \mu \mathrm{m}$ 460 and $3 \mu \mathrm{m}$ (Fig.8a). It displays also larger pores with radius in the range between 3 and $46110 \mu \mathrm{m}$, and smaller pores with radius below $0.02 \mu \mathrm{m}$. Alt mortar porosimetry curve is 462 mainly bimodal with most of their pores with radius in the range between 0.5 and $1 \mu \mathrm{m}$ 463 and pores below $0.01 \mu \mathrm{m}$ (Fig.8b).

464 3.3. Stone and hardened mortar specimens manufactured in the lab

\section{3.3.1. Mineralogical characterization}

466 Thin sections of Lit and Alt hardened mortars under optical light microscopy (Fig.9a-b 467 and Fig.9c-d respectively) show a great similitude with those samples collected from the 468 buildings (Fig. 5). The matrix or binder of the laboratory hardened mortars show lighter 469 colors and rounded pores (500 $\mu \mathrm{m}$ approx.) that could be related with a lower degree of 470 maturation and the lack of exposition to weathering agents. The small rounded pores 471 (around $50 \mu \mathrm{m}$ ) that were observed in the thin sections of Alt mortar from the building 472 are not observed in the same mortar manufactured at the lab. In the latter, there are 473 many spherical particles circa $50 \mu \mathrm{m}$ embedded in the matrix that can be clearly 474 distinguished from it by a thin rim filled with the resin (no blue dyed), which indicate 
475 spherical hollow not connected particles. The thin sections of Art mortar show 476 aggregates of calcite, quartz, feldspars and many phyllosilicates with some micas. There 477 are many small rounded pores (filled and not filled with the blue dye, which would 478 represent open and non-connected porosity), together with fissural porosity going 479 through the matrix, and intra particle porosity associated to phyllosilicates (Fig.9e and 480 9f). Euville stone thin sections show a larger size of the mineral grains compared to the 481 mortars (Fig.9g and 9h). Bioclasts, such as crinoids, sea urchins, brachiopods, coral 482 fragments and pellets can be easily recognized. Syntaxial calcite cement occupies a 483 large part of the stone that gives rise to the cohesion of the grains. Shell fragments are 484 filled with calcite sparitic cement and their edges are surrounded by sparitic and micritic 485 cement in some areas. Heterogeneous macro-pores are left by the syntaxial overgrowth 486 while micro-pores are mainly intra-particle or located between the micrite and sparite 487 crystals around shell fragments. Some quartz and clays can be also observed in minor amounts.

489 The XRD patterns of the 28 days hardened mortars manufactured in the laboratory 490 reveal the development or increase of portlandite, the decrease of larnite $\left(\mathrm{C}_{2} \mathrm{~S}\right)$ and the 491 disappearance of alite $\left(\mathrm{C}_{3} \mathrm{~S}\right)$ regarding to the analyses carried out in their corresponding 492 raw anhydrous mortars (Table 1 and Fig.10). In all the mortars the decrease of larnite 493 peaks is evident together with the improvement of crystallinity of portlandite $(\mathrm{CH})$ 494 reflected by the sharpness and intensity increase of the main $\mathrm{CH}$ peak .

495 3.3.2. Physical characterization

496 A complete characterisation of the physical properties of Euville stone and the 28 days 497 hardened mortar specimens has been done.

498 Concerning liquid water transfer (Table 6) it can be seen how Lit mortar specimens 499 display a very low capillarity coefficient compare to the rest of mortar specimens. The 
500 total amount of water at the end of the tests (Fig. 11) is also much lower than for the 501 others mortars (Fig. 11a) and Euville stone (Fig.11c). In Lit mortar specimens, 502 evaporation (water loss) is also slower than in the rest of materials but the difference is 503 less important than for capillarity (Fig.11b). Art mortar specimens get more water than 504 the others and in a very quick way. Alt mortar and Euville stone have a similar 505 behaviour during the capillarity test: similar velocity and same water content at the end 506 of the test, but Euville stone losses the water by evaporation much faster than this and 507 the other mortars (Fig.11d). At the end of the evaporation test Euville stone has lost all 508 the water taken during the capillarity test. Water vapour permeability is also quite 509 similar in Alt mortar and Euville stone. Art mortar shows the highest water vapour 510 permeability values while permeability of Lit mortar is in between the values obtained 511 in Art and Alt mortars and Euville stone. We can notice that water vapour permeability 512 and porosity are directly related; roughly we can consider that an x10E11 factor exists 513 between vapour permeability and open porosity.

514 Comparing the values of open water porosity and mercury porosity values (Table 7) it 515 can be observed that the former porosity is between 10 and $20 \%$ higher than the latter, 516 in all the materials except Lit mortar. For Lit mortar, mercury porosity is slightly higher 517 than water porosity. Bulk density corresponds to the density of "minerals" that form 518 part of these materials. Euville stone specimens have the highest bulk density $519\left(2.55 \mathrm{~g} / \mathrm{cm}^{3}\right)$, slightly lower than the calcite density $\left(2.71 \mathrm{~g} / \mathrm{cm}^{3}\right)$. Comparing the three 520 mortars, Lit mortar has the highest bulk density, followed by Alt and Art mortars. This 521 can be explained by its mineralogical composition. Apparent density depends on 522 porosity and bulk density, showing that Euville stone is more "compacted" than the 523 mortars. Concerning the mortars, Alt mortar has the highest apparent density, followed 524 by Lit and Art mortars. Apparent density is inversely related to water open porosity, i.e. 
525 the highest the open porosity the lower the apparent density. Apparent density values

526 obtained by mercury porosimetry correspond very well to values obtained by water

527 immersion test. For bulk density it can be observed the same pattern than for porosity,

528 mercury porosimetry values are slightly lower than water porosity values, except for Lit

529 mortar specimens.

530 Pore size distribution (PSD) is different for all the samples, where it can be considered

531 two different cases. First, Lit and Art mortars display a clear bimodal PSD which is

532 quite similar, with an average pore radius circa $0.10 \mu \mathrm{m}$ for Lit and $0.13 \mu \mathrm{m}$ for Art

533 mortar; median pore radius are about $0.5 \mu \mathrm{m}$ for Lit and $0.4 \mu \mathrm{m}$ for Art, in both cases

534 the median radius is higher than average radius. Alt mortar and Euville stone show

535 average pore radius higher than median radius, $0.04 \mu \mathrm{m}$ and $0.01 \mu \mathrm{m}$ for Alt mortar

536 respectively, and $1.4 \mu \mathrm{m}$ and $0.8 \mu \mathrm{m}$ for Euville stone, respectively. Euville limestone

537 has larger pores than the mortars, above $10 \mu \mathrm{m}$ (Fig.12). In all the mortars median

538 radius is smaller than the modal pick, indicating a bias to the smaller pores; Euville

539 limestone has a median bigger than the mode, reflecting the bias to the biggest pores.

540 Difference between mode and median is smaller in Euville stone than in mortars,

541 because it has a more symmetrical PSD. This difference is more important in Alt mortar

542 and we can observe a big "tail" in the distribution that takes place in the range of

543 smallest pores.

544 The comparison between capillarity coefficients and pore size distributions for Art and

545 Alt mortars and Euville limestone, indicates a direct relation between capillarity

546 coefficients and pore sizes. In order to avoid the effect of water volume absorbed during

547 the capillarity test, the capillarity coefficient (C) has been divided by the porosity values

$548(\mathrm{P})$, in this way, the obtained values correspond to the median pore radius values of

$5490.82 \mu \mathrm{m}$ (Euville), $0.41 \mu \mathrm{m}$ (Art) and $0.01 \mu \mathrm{m}$ (Alt) (Table 7). A linear regression among 
550 these values gives an equation $\mathrm{C} / \mathrm{P}=1.2461 \times$ (median pore radius) +1.9591 , with a 551 regression coefficient of $\mathrm{R}^{2}=0.9438$.

552 Results of mechanical tests obtained in these stone and hardened mortar specimens are

553 presented in Table 8. Art mortar has a mechanical behaviour different from the others, 554 since the flexural and compression strengths are much lower than the obtained in the 555 other mortars. The experimental resolution of the mechanical tests machine used is not 556 adapted to Art mortar specimens. So if this mortar is not considered, a very good linear 557 regression between flexural strength and apparent density $\left(\mathrm{R}^{2}=0.999\right)$ can be obtained.

558 The spectrocolorimetry results are compiled in Table 9. The highest total color 559 difference $\left(\Delta \mathrm{E}^{*}\right)$ between each mortar and Euville stone is obtained in Art mortar (circa 560 8), followed by Alt (circa 5) and Lit mortar that shows the lowest differences (circa 3).

\section{4. Discussion}

\section{4.1. Chemical and mineralogical characterization}

563 The original chemical and mineralogical composition of the raw anhydrous mortars 564 exert a great influence on their final physico-chemical properties in a short and in a 565 longer term, and hence on the compatibility with the stone to be repaired and their 566 durability [31]. Quartz, calcite, feldspar and larnite/belite, alite and traces of gehlenite 567 (hydraulic components, $\mathrm{C}_{2} \mathrm{~S}, \mathrm{C}_{3} \mathrm{~S}$ and $\mathrm{C}_{2} \mathrm{As}$, respectivelly) are present in the three raw 568 anhydrous mortars (Fig.3 and Table 1). The main difference in their mineralogy 569 determined is the absence of phyllosilicates in Alt mortar and the absence of aerial lime 570 (portlandite) in Lit mortar. The former contains high quantity of portlandite and calcium 571 and aluminosilicates (larnite, alite and gehlenite) while the latter has abundant 572 phyllosilicates (clinochlore and talc) and no portlandite. Art mortar composition is in 573 between the two other mortars, with portlandite, larnite and alite, and some 574 phyllosilicates (vermiculite, which was only possible to identify in the XRD and 
575 petrography of the 28 days hardened mortars and not in the XRD of the raw anhydrous 576 materials (although the presence of phyllosilicates was inferred by a small hump 577 between 10 and $15^{\circ} 2 \theta$ in the XRD pattern). The identified soluble salts determined by 578 ion chromatography represent insignificant values in the concentration in bulk material 579 (wt.\%), around $2 \%$ in Lit and Alt mortar, which should not represent a salt 580 crystallization problem or development of salt efflorescences, and a slightly higher 581 content in Art mortar (5\%). However, is important to take into account that these 582 percentages include a high concentration of soluble calcium $\left(\mathrm{Ca}^{2+}\right)$, which could be 583 combined with other anions that were no possible to identify with the chromatographic 584 column used in these analyses. Soluble calcium combined with other anions such as 585 carbonates $\left(\mathrm{CO}_{3}{ }^{2-}\right)$, silicates $\left(\mathrm{SiO}_{4}{ }^{4-}\right)$ or hydroxides $\left(\mathrm{OH}^{-}\right)$could form part of these 586 mortars, especially in Art mortar with a higher concentration of soluble $\mathrm{Ca}^{2+}$ (Table 4).

587 The characterization of stone and mortar samples collected from the historic buildings 588 has been useful to know the current composition and texture of the mortars set under 589 real conditions and five years of hardening and to study the weathering products causing 590 decay in these materials. The identification of salt minerals by XRD, SEM-EDX and the 591 quantification of soluble salts by ion chromatography have served to plan the 592 accelerated ageing test to assess the durability of stone-mortar specimens in the lab [31]. 593 The presence of chlorides and sulfates (gypsum and mixtures of calcium and sodium 594 sulfates) with minor amounts of nitrates suggest an origin of salts caused by 595 contamination/pollution coming from past restoration products and environmental 596 pollution (Fig.6, Fig.7 and Table 5).

597 Lit mortar, classified as a NHL according to the manufacturer, displays a high amount 598 of phyllosilicates that could have favour cracking of the mortar at the interface stone599 mortar observed at the Grand Palais building when mortar samples were collected 
600 (Fig.2). In the frame of Dimppa Project [32] on site measurements with non-destructive 601 techniques were carried out in this building in the same type of mortar and stone. High 602 salt index values were found at the interface between Lit mortar and Euville stone, 603 together with large differences on the thermal behaviour between both materials. 604 Restorers frequently use clay rich sands because they can increase workability and 605 matching the right colour for the restoration mortar. However, the main effect of clay 606 fines $(<63 \mu \mathrm{m})$ in aggregates is an increase of the water demand, due to their high 607 surface area, for a constant mortar consistency that gives rise to a poor quality mortar 608 [33]. However, it does not mean that NHL produce bad results in this type of restoration 609 works, it just depends on the type, proportion and grain size of the minerals in the 610 original composition and the compatibility with the stone substrate. The characterization 611 of original mortars and plasters from Crete was carried out with the evaluation of the repairs prepared with NHL as binding material, siliceous sand and crushed brick as 613 aggregates [34]. After three years of intervention with these NHL-based mortars and 614 plasters, macroscopic survey and analyses on the applied materials revealed that no 615 cracks or release of soluble salts occurred.

616 In this case, this NHL mortar collected from the Grand Palais building (Lit mortar) has 617 a higher total porosity and a polymodal pore size distribution, compared to the HL 618 mortar collected at the Préfecture de Police building (Alt mortar). The hardened mortar 619 specimens manufactured and cured during 28 days in the lab, show the presence of 620 fissural porosity mainly through the matrix of Lit mortar (Fig.9). The XRD patterns of 621 all the hardened mortars manufactured in the laboratory (Fig.10) reveal the development 622 of portlandite $(\mathrm{CH})$ in Lit mortar or its increase in Art and Alt mortars, the decrease of 623 larnite $\left(\mathrm{C}_{2} \mathrm{~S}\right)$ and the disappearance of alite $\left(\mathrm{C}_{3} \mathrm{~S}\right)$ regarding to the analyses carried out 624 in their corresponding anhydrous raw materials (Fig.3). In Art mortar the decrease of 
$625 \mathrm{C}_{2} \mathrm{~S}$ peaks can be observed together with the improvement of crystallinity of $\mathrm{CH}$ peaks

626 and the appearance of vermiculite or clinochlore peaks. In Alt and Lit mortars there is

627 also a decrease in $\mathrm{C}_{2} \mathrm{~S}$ and disappearance of $\mathrm{C}_{3} \mathrm{~S}$ peaks and the improvement of

628 crystallinity of portladite reflected by the sharpness and intensity increase of the main

629 portlandite $(\mathrm{CH})$ peak. This is explained because the hydration of $\mathrm{C}_{3} \mathrm{~S}$ and $\mathrm{C}_{2} \mathrm{~S}$ produce

$630 \mathrm{CH}$ and some of new $\mathrm{CH}$ amount can also crystallize, inside of the $\mathrm{CSH}$ (calcium

631 silicate hydrates) structure being well sheltered [13]. This fact has been related to the

632 improvement of mortar strength [35-37], while $\mathrm{C}_{3} \mathrm{~S}$ contributes to the strength at early

633 ages, $\mathrm{C}_{2} \mathrm{~S}$ and the carbonation process give their strengths at long term [13].

634 The addition of micro spherical aluminosilicate particles (diameter of $50 \mu \mathrm{m}$ ) similar to

635 fly ash (FA), into Alt mortar was confirmed through the SEM-EDS analyses, where

636 these appear empty, cracked or filled with a viscous gel rich in calcium (Fig.7b). Using

637 fly ash with small and spherical shape in mortar or concrete can reduce water demand of

638 the mixtures [38]. Chemically, fly ash has pozzolanic activity, which is attributed to the

639 presence of $\mathrm{SiO}_{2}$ and $\mathrm{Al}_{2} \mathrm{O}_{3}$. It reacts with calcium hydroxide $(\mathrm{CH})$ during cement

640 hydration, to form additional calcium silicate hydrate (CSH), calcium aluminate hydrate

641 (CAH) [39] and calcium aluminosilicate (CAS) gels. This can also be explained by the

642 denser and darker color matrix of Alt mortar under light optical microscopy and higher

643 physico-chemical compatibility with Euville stone compared the other mortars. The

644 addition of these spherical micro-capsules, seem to have been added to Alt mortar

645 mixture in order to improve the mechanical properties acting as a self-healing

646 cementitious material. Besides these spherical particles, the abundant circular air voids

647 uniformly distributed in the binder's matrix of both Alt and Art mortars, that creates an

648 apparently high visible porosity is most probably due to the addition of an air

649 entrainment agent in the mortar mix [17]. 
650 The binder:aggregate ratio between 1:3 and 1:4 of the mortars from the buildings

651 (Fig.5) is in agreement with ratios of similar mortars used in restoration works of

652 historic buildings in other countries. Pecchioni et al. in 2005 [40] study some Florentine

653 Palaces (Italy) and the analytical results show that the aggregates were composed by

654 silicate sand and the binder/aggregate ratio ranged between $1: 1$ and 1:3, with presence

655 of larnite.

656 Even though petrography and physical properties of Euville stone have been deeply 657 studied [19,20], due to its high heterogeneity, the petrography and physical properties of

658 the specific specimens used in this research was carried to study the compatibility with

659 the stone-commercial mortars. The heterogeneity of this limestone has been also

660 observed through on-site measurements on historic buildings and in-lab measurements

661 with non-destructive techniques [32].

662

\subsection{Physical characterization}

663 In this research we have characterized water (liquid and vapour) transfer through

664 mortars by means of imbibition properties (capillarity rise), evaporation (desorption

665 test) end water vapour permeability. The results show that capillarity imbibition,

666 evaporation and vapour permeability values of 28 hardened Art mortar specimens are

667 higher than in the others mortars. The reason is the high porosity of this mortar with

668 pore sizes slightly larger than the others. Alt mortar specimens have physical properties

669 close to those of Euville limestone but with a capillarity coefficient lower than the stone

670 and a very low evaporation degree.

671 The mechanical behaviour of Lit and Art mortar specimens is very different from the

672 obtained in Euville stone, being less resistant, especially in compression strength; Alt

673 mortar is the only one with higher flexural and compression strength values close to

674 those of Euville stone. 
675 The low open water porosity values of Lit mortar and the slightly higher values

676 obtained through mercury porosity compared to water porosity can be explained by the

677 hydrophobic characteristics of this mortar. Among other reasons, such as the content of

678 clays in its composition, the possible presence of a water-repellent product in the mortar

679 composition could explain crack formation, observed both at the interface of stone-

680 mortar repaired areas at the Grand Palais building. Besides, in the case of these Lit

681 mortar specimens, also a smooth coating is observed on the surface. This surface

682 coating, 'skin' or 'scum' is known as laitance and is formed when fine lime particles

683 held in suspension migrate to the outer surface of the wet material. This laitance is

684 believed to hinder the vapour permeability of lime-based materials, and negatively

685 impact upon the substrate beneath by causing accelerated masonry decay associated

686 with entrapment of moisture. Therefore, it is recommended to remove this laitance from

687 this type of restoration mortar, especially when applied to permeable substrates [9].

688 From the results of the mechanical properties, especially flexural strength, in the case of

689 Alt and Lit mortars and Euville stone it depend, on the apparent density of the material,

690 which is a function of porosity and bulk (mineral) density. $\mathrm{C}_{2} \mathrm{~S}$ phases, such as larnite,

691 and the carbonation process provide strength in a longer term, while limestone

692 aggregates also increase strength, due to the calcite syntaxial growth, which develops

693 strength thereby enhancing the binder-aggregate interface [13]. This can explain the

694 highest strength values in Alt mortar specimens with higher content in these mineral 695 phases.

696 Regarding to spectrophotometry results, the highest total colour difference $\left(\Delta \mathrm{E}^{*}\right)$ 697 between each mortar and Euville stone is obtained in Art mortar (circa 8), followed by 698 Alt (circa 5) and Lit mortar that shows the lowest differences (circa 3). According to 699 suitability criteria used to assess conservation treatments, $\Delta \mathrm{E}^{*}$ values lower than 5 
according to the standard NORMAL 20/85 [41], and close to 3 according to other authors

701 [42,43], would not be visually detectable by the human eye and it would not significantly affect the colorimetric parameters of the substrate, which only Lit and Alt 703 mortars would fulfil this criteria after 28 days of hardening.

704 Repair mortars used for stone restoration are assumed to be highly compatible with 705 historic materials in terms of physical, chemical and mechanical properties in order to 706 assure the durability of masonry on the long term [3]. In this sense, these characteristics 707 in Alt mortar are closer to those of Euville stone, compared to the other mortars, with 708 the exception of some differences in the hydric properties due to their different pore 709 systems and aesthetic features that should be improved in further restoration works. The 710 obtained results cannot allow us to conclude which is the best mortar to restore Euville 711 stone, and further studies about mortar-stone interactions will be necessary. This work 712 is an essential step on the research concerning the compatibility and the potential 713 durability of mortars and stone in masonry building restoration.

\section{5. Conclusions}

715 The chemical and mineralogical composition of Euville limestone,(mainly composed of 716 calcium carbonate) and all the studied anhydrous hydraulic mortars (NHL, HL) 717 composed by di-calcium silicate $\left(\mathrm{C}_{2} \mathrm{~S}\right.$,larnite/belite $)$, tri-calcium silicate $\left(\mathrm{C}_{3} \mathrm{~S}\right.$, alite $)$, 718 traces of di-calcium alumina silicate $\left(\mathrm{C}_{3} \mathrm{AS}\right.$, gehlenite $)$ with presence or absence of 719 phyllosilicates (vermiculite, clinochlore and talc) and aerial lime (portlandite) seems to 720 be critical in the chemistry of the 28 days hardened mortars. The mortar containing 721 calcite, portlandite and no phyllosilicates (Altar Pierre) shows better chemical and 722 mineralogical compatibility with the stone.

723 The soluble salts content of the raw anhydrous mortars is negligible. The presence of 724 chlorides and sulfates (gypsum and mixtures of calcium and sodium sulfates) with 
725 minor amounts of nitrates present in mortar samples collected from historic buildings of

726 Paris suggest an origin of salts caused by contamination/pollution coming from past

727 restoration products and environmental pollution.

728 Regarding to physical compatibility, the mortars containing higher amounts of 729 phyllosilicates (clinochlore and talc) develop cracks on their surfaces or fissures close to

730 the stone-mortar interface, as observed in Lithomex mortar samples collected from

731 Grand Palais building. However, the aesthetical compatibility obtained from the total 732 color difference values between this mortar and the stone indicates that this is not 733 visually detectable by the human eye.

734 The addition of marble aggregates and 50-micron spherical aluminosilicate particles to 735 Altar Pierre mortar, favoured hydrolyses reactions and produced a lower porosity matrix 736 with closer hydric and mechanical properties to those of the Euville stone compared to 737 the other two mortars. So, the physico-chemical properties of this mortar are closer to 738 those of the stone, with the exception of some differences in the hydric behaviour due to 739 their different pore systems and aesthetic features that should be improved in further 740 restoration works.

\section{Acknowledgements}

742 Thanks to Foundation des Sciences du Patrimoine / LabEx PATRIMA (2014-2015) for 743 founding the project "Durabilité de l'interaction Mortier-Pierre dans le patrimoine 744 architectural" (acronym: Dimppa) that allowed to carry out this research and the 745 postdoctoral contract of Dr. Lopez-Arce. Thanks also to Roland Westphal (Entreprise 746 Lefèvre) for showing us the restoration works carried out at the Grand Palais. Special 747 thanks to Mrs Ch. Garrat from Grand Palais and Mrs Keller from Préfecture de Police 748 for their decisive help during sampling on the monuments. We are also grateful to Lilian 749 Cristofol and technical engineers that helped in sample preparation and SEM-EDS 
analyses from the Civil Engineering Dept. Cergy-Pontoise University (UCP) Finally

751

752 special thanks as well to Isabell Laureat from the Chemistry Dept. of UCP for all her help performing the calibration of the ion chromatography (IC) equipment.

\section{References}

754 [1] J. Válek, Members of RILEM TC-203-RHM, Performance and Repair Requirements 755 for surface repairs, in: HMC2010 conference and TC 203-RHM final workshop, Prague, 756 September 22-24 Rilem Publications s.a.r.l., 2010, pp. 1377-1383.

757 [2] J. Griswold, S. Uricheck, Loss Compensation Methods for Stone, JAIC 37 (1998) 758 89-110.

759 [3] K. Van Balen, E.E. Toumbakari, M.T. Blanco, J. Aguilera, F. Puertas, C. Sabbioni, 760 G. Zappia, C. Riontino, G. Gobbi, Procedure for a mortar type identification, a proposal, 761 in: P. Bartos, C. Groot, J.J. Hughes (Eds.), Proceedings of International RILEM 762 Workshop on Historic Mortars: Characteristics and Tests, Paisley, Scotland, May 12-14, 763 Rilem Publications s.a.r.1. 1999, pp. 63-72 (1999).

764 [4] C. Groot, G. Ashall, J. Hughes. Report of RILEM TC COM 167: characterisation of 765 old mortars with respect to their repair. RILEM Report 28, RILEM Publications s.a.r.l., 766 France (2004).

767 [5] J. Ashurst. N. Ashurst, Practical Building Conservation, English Heritage 768 Handbook, Vol.1, Stone masonry, Gower technical Press ltd (1990).

769 [6] J.J. Hughes, J. Válek, Mortars in historic buildings. A review of the scientific and 770 conservation literature, Historic Scotland, Edinburgh (2003).

771 [7] P. Lopez-Arce, J. Garcia-Guinea, D. Benavente, L. Tormo, E. Doehne, Deterioration 772 of dolostone by magnesium sulfate salt: An example of incompatible building materials 773 at Bonaval Monastery, Spain. Constr. Build. Mater. 23 (2009) 846-855. 
774 [8] I. Papayianni, M. Stefanidou, Strength-porosity relationships in lime-pozzolan 775 mortars. Constr. Build. Mater. 20 (2006) 700-705.

776 [9] C. Torney, A.M. Forster, P.F.G. Banfill, E.M. Szadurski, The effects of site practice 777 on the physical properties of proprietary stone restoration mortar. Constr Build Mater 75 778 (2015) 359-367.

779 [10] A. Isebaert, L. Van Parys, V. Cnudd, Composition and compatibility requirements 780 of mineral repair mortars for stone - A review. Constr. Build. Mater. 59 (2014) 39-50.

781 [11] B. Szemerey-Kiss, A. Török, Time-dependent changes in the strength of repair 782 mortar used in the loss compensation of stone. Environ Earth Sci. 63 (2011) 1613-1621.

783 [12] V. Rahhal, R. Talero, Effect of three natural pozzolans on portland cement 784 hydration, Mater. Construcc. 53 (2003) 29-40.

785 [13] J. Lanas, J.L. Perez Bernal, M.A. Bello, J.I. Alvarez Galindo, Mechanical 786 properties of natural hydraulic lime-based mortars. Cem. Concr. Res. 34 (2004) 21917872201.

788 [14] K. Callebaut, J. Elsen, K. Van Balen, W. Viaen, Nineteenth century hydraulic 789 restoration mortars in the Saint Michael's Church (Leuven, Belgium) Natural hydraulic 790 lime or cement? Cem. Concr. Res. 31 (2001) 397-403.

791 [15] J.M. Teutonico, G. Ashall, E. Garrod, T. Yates, A comparative study of hydraulic 792 lime-based mortars, in: P. Bartos, C. Groot, J.J. Hughes (Eds.), Proceedings of 793 International RILEM Workshop on Historic Mortars: Characteristics and Tests, Paisley, 794 Scotland, May 12-14, Rilem Publications s.a.r.1. 1999, pp. 339-349 (1999).

795 [16] L. Schueremans, Ö. Cizer, G. Serré, K.V. Balen, Characterization of repair 796 mortars for the assessment of their compatibility in restoration projects: Research and 797 practice, Constr. Build. Mater. 25 (2011) 4338-4350. 
798 [17] D. Gulotta, S. Goidanich, C. Tedeschi, T.G. Nijland, L. Toniolo, Commercial 799 NHL-containing mortars for the preservation of historical architecture. Part 1: 800 Compositional and mechanical characterisation, Cem. Concr. Res. 38 (2013) 31-42.

801 [18] C. Pelosi, U. Santamaria, G. Agresti, G. De Vivo, D. Bandera, Analysis and 802 laboratory tests to evaluate the composition and the behaviour of some dehumidifying 803 mortars used in the restoration field, Periodico di Mineralogia, 82 (2013) 557-572.

804 [19] T. De Kock, J. Dewanckele, M. Boone, G. de Schutter, P. Jacobs, V. Cnudde, 805 Replacement stones for Lede stone in Belgian historical monuments, in: J. Cassar, M.G. 806 Winter, B.R. Marker, N.R.G. Walton, D.C. Entwisle, E.N. Bromhead, J.W.N. Smith 807 (Eds.), Stone in Historic Buildings: Characterization and Performance, Geological 808 Society, London, Special Publications 391, 2014, pp. 31-46.

809 [20] J. Dewanckele, T. De Kock, G. Fronteau, H. Derluyn, P. Vontobel, M. Dierick, L. 810 Van Hoorebeke, P. Jacobs, V. Cnudde, Neutron radiography and X-ray computed 811 tomography for quantifying weathering and water uptake processes inside porous 812 limestone used as building material, Mater. Charact. 88 (2014) 86-99.

813 [21] EN 12620 + A1:2008 (2002) Aggregates for Concrete.

814 [22] AFNOR EN 196-1 (2006) Méthodes d'essai des ciments Partie 1: Détermination de 815 la résistance mécaniques, France.

816 [23] AFNOR EN 1015-11, Méthodes d'essai des mortiers pour maçonnerie. Partie 11: 817 Détermination de la résistance en flexion et en compression du mortier durci, France 8182000.

819 [24] A. Arizzi, G. Martínez- Huerga, E. Sebastian-Pardo, G. Cultrone, Mineralogical, 820 textural and physical-mechanical study of hydraulic lime mortars cured under different 821 moisture conditions, Mater. Construcc. 65 (2015). 
822 [25] A. Arizzi, H. Viles, G. Cultrone, Experimental testing of the durability of lime-

823 based mortars used for rendering historic buildings, Constr. Build. Mater. 28 (2012)

$824 \quad 807-818$.

825 [26] AFNOR NF-EN 1015-1(P12-301), Méthodes d'essai des mortiers pour 826 maçonnerie. Partie 1: Détermination de la répartition granulométrique (par tamisage), 827 France, 1999.

828 [27] AFNOR EN 1925, Méthodes d'essai pour Pierres naturelles Détermination du 829 coefficient d'absorption d'eau par capillarité, France, 1999.

830 [28] AFNOR EN 15803, Méthodes d'essai : détermination de la perméabilité à la 831 vapeur d'eau, France, 2010.

832 [29] AFNOR EN 1936, Méthodes d'essai des Pierres naturelles maçonnerie : 833 Détermination des masses volumiques réele et apparentes et des porosités ouverte et 834 totale, France, 2007.

835 [30] AFNOR EN 196-1, Méthodes d'essai des ciments Partie 1: Détermination de la 836 résistance mécaniques, France, 2006.

837 [31] P. Lopez-Arce, M. Tagnit-Hammou, B. Menendez, J-D. Mertz, A. Kaci, Durability 838 of stone-repair mortars used in historic buildings from Paris, Materials and Structures, 839 DOI 10.1617/s11527-016-0846-0

840 [32] B. Menendez, J.D. Mertz, M. Guiavarc'h, A. Kaci, S. Aggoun, P. Lopez-Arce, 841 Durabilité de l'interaction Mortier-Pierre dans le patrimoine architectural (acronym: 842 Dimppa project). Foundation des Sciences du Patrimoine / LabEx PATRIMA (2014843 2015), Final technical report.

844 [33] F. Winnefeld, K.G. Böttger, How clayey fines in aggregates influence the 845 properties of lime mortars. Mater. Struct. 39 (2006) 433-443. 
846 [34] P. Maravelaki-Kalaitzaki, A. Bakolas, I. Karatasios, V. Kilikoglou, Hydraulic lime

847 mortars for the restoration of historic masonry in Crete, Cem. Concr. Res. 35 (2005) $848 \quad 1577-1586$.

849 [35] A. Moropoulou, A. Bakolas, K. Bisbikou, Physico-chemical adhesion and cohesion 850 bonds in joint mortars imparting durability to the historic structures, Constr. Build. 851 Mater. 14 (2000) 35-46.

852 [36] A. Moropoulou, A. Bakolas, K. Bisbikou, Investigation of the technology of 853 historic mortars, J. Cult. Herit. 1 (2000) 45- 58.

854 [37] A. Moropoulou, G. Biscontin, A. Bakolas, K. Bisbikou, Technology and behavior 855 of rubble masonry, Constr. Build. Mater. 11 (1997) 119-129.

856 [38] E.P. Mora, J. Paya, J. Monzo, Influence of different sized fractions of a fly ash on 857 workability of mortars. Cem. Concr. Res. 23 (1993) 917-924.

858 [39] L.J. Malvar, L.R. Lenke, Efficiency of fly ash in mitigating alkali silica reaction 859 based on chemical composition, ACI Mater. J. 103 (2006) 319-326.

860 [40] E. Pecchioni, P. Malesani, B. Bellucci, F. Fratini, Artificial stones utilised in 861 Florence historical palaces between the XIX and XX centuries, J. Cult. Herit. 6 (2005) $862 \quad 227-233$.

863 [41] NORMAL 20/85, Interventi conservativi: progettazione esecuzione e valutazione 864 preventive, Italy, 1986.

865 [42] D. Benavente, F. Martinez-Verdu, A. Bernabeu, V. Viqueira, R. Fort, M.A. Garcia 866 del Cura, C. Illueca, S. Ordoñez, Color Res. Appl. 28 (2003) 343-351.

867 [43] J.D. Rodrigues, A. Grossi, Indicators and ratings for the compatibility assessment 868 of conservation actions, J. Cult. Herit. 8 (2007) 32-43. 
871 Figure 1. Mortar and stone materials. a) Raw anhydrous ready to mix mortars (left: Lit mortar;

872 center: Alt mortar; right: Art mortar); b) Euville stone specimen used for water vapour 873 permeability test; c) 28 days hardened mortars specimens (Left: Lit mortar; center: Alt mortar; right: Art mortar) after capillarity water absorption test.

875 Figure 2. Mortar and stone samples collected from historic buildings of Paris. a) Lit mortar 876 from Grand Palais building; b) Alt mortar from Préfecture Police building; c) Euville stone 877 flake from Préfecture Police.

878 Figure 3. X-ray diffraction patterns (XRD) of the raw anhydrous mortars (Lit: Lithomex; Art: 879 ArtoPierre;. Alt: Altar Pierre)

880 Figure 4. SEM-EDS analyses performed in several areas of mineral grains with sizes between 881 1.6-1.25 mm and $1.25 \mathrm{~mm}-0.63 \mathrm{~mm}$ of Lithomex (Litho, Lit), ArtoPierre (Arto, Art) and Altar 882 Pierre (Altar, Alt) mortars. a) phyllosilicates (clinochlore and talc), with and without additional $883 \mathrm{~K}$, Ti and $\mathrm{Cl}$ with sizes between $1.6-1.25 \mathrm{~mm}$ in Lit mortar; b) calcite grains $(1.25 \mathrm{~mm}-0.63$ $884 \mathrm{~mm})$ in Lit mortar; c) phyllosilicates $(1.25-063 \mathrm{~mm})$ in Art mortar; d) calcite grains $(1.25 \mathrm{~mm}$ $8850.63 \mathrm{~mm})$ in Alt mortar.

886 Figure 5. Thin sections obtained by light optical microscopy in mortar samples collected from 887 historic buildings of Paris. a) Lit mortar from Grand Palais building (Lit-GP); b) same former 888 image with crossed nicols; c) Lit mortar, detail of fissural porosity (in blue); d) same former 889 image with crossed nicols; e) Alt mortar from Préfecture Police building (Alt-PP); f) same 890 former image with crossed nicols; g) Alt mortar, detail of same sample showing porosity (in 891 blue).

892 Figure 6. X-ray diffraction pattern of mortar samples collected from historic buildings of Paris. 893 Lit-GP (Lithomex mortar from Grand Palais); Alt -PP (Altar Pierre from Préfecture Police); Lit894 GP-sf (evaporated soluble fraction together with non-soluble residues). 
895 Figure 7. Scanning electron microscopy (SEM) images and energy dispersive spectroscopy 896 (EDS) analyses performed on the surface of mortar and stone samples collected from historic 897 buildings of Paris. a) Lit mortar from the Grand Palais; b) Alt mortar from Préfecture de Police; 898 c) efflorescences in Euville stone flake from Préfecture de Police.

899 Figure 8. Connected porosity and pore size distribution obtained by mercury intrusion 900 porosimetry in mortar samples collected from historic buildings of Paris. a) Lit mortar from 901 Grand Palais; b) Alt mortar from Préfecture de Police.

902

903 Figure 9. Thin sections observed by light optical microscopy of the 28 days hardened mortars 904 manufactured in the lab and of Euville stone. a) Lit mortar with parellel nicols; b) same former 905 image with crossed nicols; c) Alt mortar with parellel nicols; d) same former image with 906 crossed nicols; e) Art mortar with parellel nicols; f) same former image with crossed nicols; g) 907 Euville stone with parellel nicols; h) same former image with crossed nicols.

908 Figure 10. X-ray diffraction pattern of 28 days (28d) hardened mortars manufactured in the 909 laboratory (Lit: Lithomex mortar; Art: Artopierre mortar; Alt: Altar Pierre mortar).

910 Figure 11. Representation of hydric properties of 28 days hardened mortars and stone 911 specimens. a) capillarity water absorption of mortars; b) water desorption (water loss) of 912 mortars; c) capillarity water absorption of Euville stone; d) water desorption (water loss) of 913 Euville; e) water vapor permeability of mortars; f) water vapor permeability of Euville stone.

914 Figure 12. Connected porosity and pore size distribution obtained by mercury intrusion 915 porosimetry in 28 days hardened mortars and Euville stone. 
917 Table 1. Semi-quantitative (\%) X-ray diffraction (XRD) analyses of the raw anhydrous and 28 days hardened mortars together with mortar samples 918 from historic buildings from Paris

\begin{tabular}{|c|c|c|c|c|c|c|c|c|c|c|c|c|c|}
\hline Mortar & Calcite & Quartz & Feldspar & Gypsum & Clinochlore & Talc & Dolomite & Muscovite & $\mathrm{C}_{3} \mathrm{~S}$ & $\mathrm{C}_{2} \mathrm{~S}$ & $\mathrm{C}_{2} \mathrm{AS}$ & $\mathrm{CH}$ & halite \\
\hline Lit-raw & 20 & 10 & 5 & $\mathrm{Nd}^{*}$ & 10 & 45 & traces & $\mathrm{Nd}^{*}$ & 5 & 5 & traces & $\mathrm{Nd}^{*}$ & $\mathrm{Nd}^{*}$ \\
\hline Art-raw & 15 & 50 & traces & $\mathrm{Nd}^{*}$ & $\mathrm{Nd}^{*}$ & $\mathrm{Nd}^{*}$ & $\mathrm{Nd}^{*}$ & $\mathrm{Nd}^{*}$ & 5 & 10 & traces & 20 & $\mathrm{Nd}^{*}$ \\
\hline Alt-raw & 20 & 35 & 15 & traces & $\mathrm{Nd}^{*}$ & $\mathrm{Nd}^{*}$ & $\mathrm{Nd}^{*}$ & $\mathrm{Nd}^{*}$ & 5 & 10 & traces & 15 & $\mathrm{Nd}^{*}$ \\
\hline Lit-GP* & 14 & 14 & 10 & 5 & 21 & 20 & $\mathrm{Nd}^{*}$ & 16 & $\mathrm{Nd}^{*}$ & $\mathrm{Nd}^{*}$ & traces & $\mathrm{Nd}^{*}$ & $\mathrm{Nd}^{*}$ \\
\hline Lit-GP-sf* & 15 & 5 & $\mathrm{Nd}^{*}$ & 8 & 49 & 18 & $\mathrm{Nd}^{*}$ & $\mathrm{Nd}^{*}$ & $\mathrm{Nd}^{*}$ & $\mathrm{Nd}^{*}$ & $\mathrm{Nd}^{*}$ & $\mathrm{Nd}^{*}$ & 5 \\
\hline Alt-PP & 15 & 60 & 14 & $\mathrm{Nd}^{*}$ & $\mathrm{Nd}^{*}$ & $\mathrm{Nd}^{*}$ & $\mathrm{Nd}^{*}$ & $\mathrm{Nd}^{*}$ & $\mathrm{Nd}^{*}$ & 6 & traces & 5 & $\mathrm{Nd}^{*}$ \\
\hline Lit-28D & 20 & 21 & 5 & $\mathrm{Nd}^{*}$ & 26 & 28 & $\mathrm{Nd}^{*}$ & $\mathrm{Nd}^{*}$ & $\mathrm{Nd}^{*}$ & traces & $\mathrm{Nd}^{*}$ & $\mathrm{Nd}^{*}$ & $\mathrm{Nd}^{*}$ \\
\hline Art-28D & 20 & 61 & 9 & $\mathrm{Nd}^{*}$ & traces & $\mathrm{Nd}^{*}$ & $\mathrm{Nd}^{*}$ & $\mathrm{Nd}^{*}$ & $\mathrm{Nd}^{*}$ & 5 & traces & 5 & $\mathrm{Nd}^{*}$ \\
\hline Alt-28D & 18 & 50 & 20 & $\mathrm{Nd}^{*}$ & $\mathrm{Nd}^{*}$ & $\mathrm{Nd}^{*}$ & $\mathrm{Nd}^{*}$ & $\mathrm{Nd}^{*}$ & traces & 6 & traces & 6 & $\mathrm{Nd}^{*}$ \\
\hline
\end{tabular}

922

Table 2. Qualitative elemental analyses performed by punctual energy dispersive spectroscopy (SEM-EDS) on several

\begin{tabular}{|l|l|l|l|l|l|l|}
\hline Mortar & Lit mortar & Art mortar & \multicolumn{3}{l|}{ Alt mortar } \\
\hline Grain size interval & $1.60-1.25 \mathrm{~mm}$ & $1.25-0.63 \mathrm{~mm}$ & $1.60-1.25 \mathrm{~mm}$ & $1.25-0.63 \mathrm{~mm}$ & $1.60-1.25 \mathrm{~mm}$ & $1.25-0.63 \mathrm{~mm}$ \\
\hline Normalized wt.\% & & & & & & \\
\hline $\mathrm{Ca}$ & Present & Present & Present & Present & Present & Present \\
\hline $\mathrm{Si}$ & Present & Present & Present & Present & Present & Present \\
\hline $\mathrm{Al}$ & Present & Present & Present & Present & No detected & No detected \\
\hline $\mathrm{Mg}$ & Present & Present & Present & Present & No detected & No detected \\
\hline $\mathrm{O}$ & Present & Present & Present & Present & Present & Present \\
\hline $\mathrm{C}$ & Present & Present & Present & Present & Present & Present \\
\hline $\mathrm{K}$ & Present & No detected & Present & Present & No detected & No detected \\
\hline $\mathrm{Na}$ & Present & Present & Present & No detected & Present & No detected \\
\hline $\mathrm{Fe}$ & Present & Present & Present & Present & No detected & Present \\
\hline $\mathrm{Ti}$ & Present & No detected & Present & Present & No detected & Present \\
\hline $\mathrm{Cl}$ & Present & No detected & Present & Present & Present & Present \\
\hline
\end{tabular}



binder) of the raw anhydrous mortars pressed on tablets.

\begin{tabular}{|l|l|l|}
\hline Grain size & $0.63-0.315 \mathrm{~mm}$ & $0.315-0.20 \mathrm{~mm}$ \\
\hline & &
\end{tabular}

\begin{tabular}{l|l|l|l|l|} 
& \multicolumn{2}{|l|}{$0.20-0.16 \mathrm{~mm}$} & $0.16-0.080 \mathrm{~mm}$ & $<0.080 \mathrm{~mm}$
\end{tabular}

\begin{tabular}{|c|c|c|c|c|c|c|c|c|c|c|c|c|c|c|c|}
\hline Mortar & Lit & Art & Alt & Lit & Art & Alt & Lit & Art & Alt & Lit & Art & Alt & Lit & Art & Alt \\
\hline \multicolumn{16}{|c|}{ Normalized wt.\% } \\
\hline $\mathrm{Ca}$ & 13.1 & 19.7 & 3.8 & 11.0 & 11.3 & 5.4 & 9.3 & 38.3 & 27.0 & 7.5 & 32.6 & 28.3 & 3.9 & 39.7 & 33.0 \\
\hline $\mathrm{Si}$ & 19.2 & 23.0 & 39.0 & 20.7 & 33.1 & $\begin{array}{l}41 . \\
2\end{array}$ & 11.0 & 8.0 & 6.3 & 5.2 & 5.5 & 5.6 & 8.0 & 2.4 & 6.3 \\
\hline $\mathrm{Al}$ & 0.5 & 0.4 & 1.1 & 0.6 & 0.6 & 1.5 & 0.8 & 0.4 & 1.4 & 1.2 & 0.5 & 1.7 & 1.9 & 0.5 & 1.8 \\
\hline $\mathrm{Mg}$ & 0.5 & 0.5 & 0.2 & 0.4 & 0.4 & 0.2 & 1.2 & 0.4 & 1.8 & 4.8 & 0.5 & 2.2 & 7.7 & 0.5 & 1.8 \\
\hline 0 & 52.3 & 45.6 & 50.8 & 50.7 & 48.0 & $\begin{array}{l}48 . \\
0\end{array}$ & 59.8 & 46.7 & 54.8 & 61.8 & 52.5 & 54.0 & 61.9 & 49.1 & 50.2 \\
\hline C & 12.6 & 10.8 & 4.6 & 14.7 & 6.2 & 2.5 & 17.6 & 5.8 & 7.1 & 19.3 & 7.4 & 7.3 & 16.1 & 7.3 & 6.0 \\
\hline $\mathrm{S}$ & 0.0 & 0.0 & 0.0 & 0.0 & 0.0 & 0.0 & 0.0 & 0.4 & 1.0 & 0.3 & 0.4 & 0.7 & 0.4 & 0.4 & 0.8 \\
\hline $\mathrm{K}$ & 0.2 & 0.0 & 0.8 & 0.2 & 0.4 & 1.2 & 0.0 & 0.2 & 0.1 & 0.0 & 0.2 & 0.0 & 0.0 & 0.1 & 0.0 \\
\hline $\mathrm{Na}$ & 0.0 & 0.0 & 3.8 & 0.0 & 0.0 & 5.4 & 0.0 & 0.0 & 27.0 & 0.0 & 0.4 & 0.4 & 0.0 & 0.0 & 33.0 \\
\hline
\end{tabular}

931 Table 4. Soluble salt content determined by ion chromatography analyses of the raw anhydrous mortars

\begin{tabular}{|c|c|c|c|c|c|c|c|c|c|c|c|}
\hline \multirow{2}{*}{\multicolumn{2}{|c|}{$\begin{array}{l}\text { Soluble salts } \\
\text { Samples }\end{array}$}} & \multicolumn{4}{|c|}{ Anions (ppm) } & \multicolumn{5}{|c|}{ Cations (ppm) } & \multirow{3}{*}{$\begin{array}{l}\text { Wt. } \\
(\%) \\
2\end{array}$} \\
\hline & & $\mathrm{Cl}^{-}$ & $\mathrm{SO}_{4}{ }^{2-}$ & $\mathrm{NO}_{3}{ }^{-}$ & $\mathrm{PO}_{4}^{3-}$ & $\mathrm{Na}^{+}$ & $\mathrm{NH}_{4}^{+}$ & $\mathrm{K}^{+}$ & $\mathrm{Mg}^{2+}$ & $\mathrm{Ca}^{2+}$ & \\
\hline anhydrous & Lit & 5 & 23 & 0 & 0 & 22 & 0.00 & 3 & 1 & 129 & \\
\hline \multirow[t]{2}{*}{ mortar } & Art & 5 & 0 & 0 & 0 & 16 & 0.00 & 3 & 1 & 534 & 5 \\
\hline & Alt & 6 & 0 & 0 & 0 & 22 & 0.00 & 3 & 3 & 165 & 2 \\
\hline
\end{tabular}


933 Table 5. Soluble salt content determined by ion chromatography analyses of mortar and stone samples collected from Grand

934 Palais (GP) and Préfecture Police (PP) buildings.

\begin{tabular}{|c|c|c|c|c|c|c|c|c|c|c|c|}
\hline \multirow{2}{*}{\multicolumn{2}{|c|}{$\begin{array}{l}\text { Soluble salts } \\
\text { Samples }\end{array}$}} & \multicolumn{4}{|c|}{ Anions (ppm) } & \multicolumn{5}{|c|}{ Cations (ppm) } & \multirow{3}{*}{$\begin{array}{l}\text { wt. } \\
(\%) \\
3\end{array}$} \\
\hline & & $\mathrm{Cl}^{-}$ & $\mathrm{SO}_{4}^{2-}$ & $\mathrm{NO}_{3}{ }^{-}$ & $\mathrm{PO}_{4}^{3-}$ & $\mathrm{Na}^{+}$ & $\mathrm{NH}_{4}^{+}$ & $\mathrm{K}^{+}$ & $\mathrm{Mg}^{2+}$ & $\mathrm{Ca}^{2+}$ & \\
\hline Mortar & Lit-GP & 30 & 105 & 25 & 0 & 22 & 0 & 9 & 5 & 97 & \\
\hline $\begin{array}{l}\text { From } \\
\text { buildings }\end{array}$ & Alt-PP & 12 & 21 & 34 & 0 & 17 & 0 & 2 & 2 & 15 & 1 \\
\hline Stone flake & EU-PP & 17 & 984 & 0 & 0 & 58 & 0 & 152 & 7 & 261 & 13 \\
\hline
\end{tabular}

936 Table 6. Results from hydric characterization of 28 days hardened mortars and stone specimens

\begin{tabular}{|l|c|c|c|c|}
\hline Properties / samples & Lit mortar & Art mortar & Alt mortar & Euville stone \\
\hline Capillary & 11.63 & 73.85 & 43.20 & 45.60 \\
Coefficient $\left(\mathrm{g} / \mathrm{m}^{2} \cdot \mathrm{s}^{0.5}\right)$ & -5.16 & -29.41 & -7.79 & -49.80 \\
\hline $\begin{array}{l}\text { Desorption Coefficient } \\
\left(\mathrm{g} / \mathrm{m}^{2} . \mathrm{s}^{0.5}\right)\end{array}$ & & & & \\
\hline
\end{tabular}




\begin{tabular}{|l|c|c|c|c|}
\hline Water vapour permeability & $3.08 \mathrm{E}-11$ & $4 \mathrm{E}-11$ & $1.79 \mathrm{E}-11$ & $1.57 \mathrm{E}-11$ \\
$\mathrm{Kg} /(\mathrm{m} . \mathrm{s} . \mathrm{Pa})$ & & & & \\
\hline Open porosity $(\%)$ & $31.1 \pm 1.1$ & $39.1 \pm 1.0$ & $25.0 \pm 0.2$ & $16.5 \pm 1.0$ \\
\hline Apparent density $\left(\mathrm{g} / \mathrm{cm}^{3}\right)$ & $1.67 \pm 0.00$ & $1.58 \pm 0.01$ & $1.88 \pm 0.03$ & $2.25 \pm 0.02$ \\
\hline Bulk density $\left(\mathrm{g} / \mathrm{cm}^{3}\right)$ & $2.45 \pm 0.04$ & $2.59 \pm 0.00$ & $2.51 \pm 0.01$ & $2.69 \pm 0.01$ \\
\hline
\end{tabular}

937

938 Table 7. Mercury intrusion porosimetry results obtained in 28 days hardened mortars and stone

\begin{tabular}{|l|c|c|c|c|}
\hline Properties / samples & Lit mortar & Art mortar & Alt mortar & Euville stone \\
\hline Porosity $(\%)$ & 32.24 & 31.77 & 21.13 & 14.92 \\
\hline Apparent density $\left(\mathrm{g} / \mathrm{cm}^{3}\right)$ & 1.69 & 1.57 & 1.88 & 2.17 \\
\hline Bulk density $\left(\mathrm{g} / \mathrm{cm}^{3}\right)$ & 2.49 & 2.30 & 2.38 & 2.55 \\
\hline Average pore radius $(\mu \mathrm{m})$ & 0.10 & 0.13 & 0.04 & 1.47 \\
\hline Median pore radius $(\mu \mathrm{m})$ & 0.48 & 0.41 & 0.01 & 0.82 \\
\hline Mode pore radius $(\mu \mathrm{m})$ & 0.76 & $0.95(0.28)$ & $0.34(0.25)$ & 0.60 \\
\hline
\end{tabular}


940 Table 8. Flexural and compression strength of 28 days hardened mortars and Euville stone.

\begin{tabular}{|l|l|l|l|l|}
\hline Strength (MPa) & Lit mortar & Art mortar & Alt mortar & Euville stone \\
\hline Flexural & $3.91 \pm 0.05$ & $2.22 \pm 0.08$ & $4.22 \pm 0.16$ & $4.84 \pm 0.35$ \\
\hline Compression & $9.01^{*}$ & $<7$ & $15.65 \pm 2.88$ & $27.07 \pm 5.25$ \\
\hline
\end{tabular}

* In the other specimens compression was $<7$

942 Table 9. Colour parameters ( $\mathrm{L}^{*}$, lightness; $\mathrm{a}^{*}$ and $\mathrm{b}^{*}$ colour coordinates; $\mathrm{C}^{*}$, Chroma; $\Delta \mathrm{E}^{*}$, total colour difference) obtained in 94328 days hardened mortar specimens and Euville stone.

\begin{tabular}{|l|l|l|l|l|l|l|}
\hline Material & $\mathrm{L}^{*}$ & $\mathrm{a}^{*}$ & $\mathrm{~b}^{*}$ & $\mathrm{C}^{*}(\mathrm{D} 65)$ & Hue (D65) & $\Delta \mathrm{E}^{*}$ \\
\hline Lit & $78.44 \pm 0.10$ & $2.35 \pm 0.02$ & $11.32 \pm 0.04$ & $11.56 \pm 0.04$ & $78.30 \pm 0.06$ & 3.22 \\
\hline Art & $88.05 \pm 0.11$ & $0.93 \pm 0.03$ & $6.34 \pm 0.08$ & $6.47 \pm 0.08$ & $81.72 \pm 0.13$ & 7.80 \\
\hline Alt & $76.36 \pm 0.06$ & $1.60 \pm 0.01$ & $9.56 \pm 0.03$ & $9.70 \pm 0.04$ & $80.50 \pm 0.06$ & 5.16 \\
\hline Stone & $81.38 \pm 1.09$ & $2.68 \pm 0.28$ & $10.06 \pm 1.44$ & $10.41 \pm 1.45$ & $74.98 \pm 1.46$ & Reference \\
\hline
\end{tabular}

944

945 
FIGURE 1

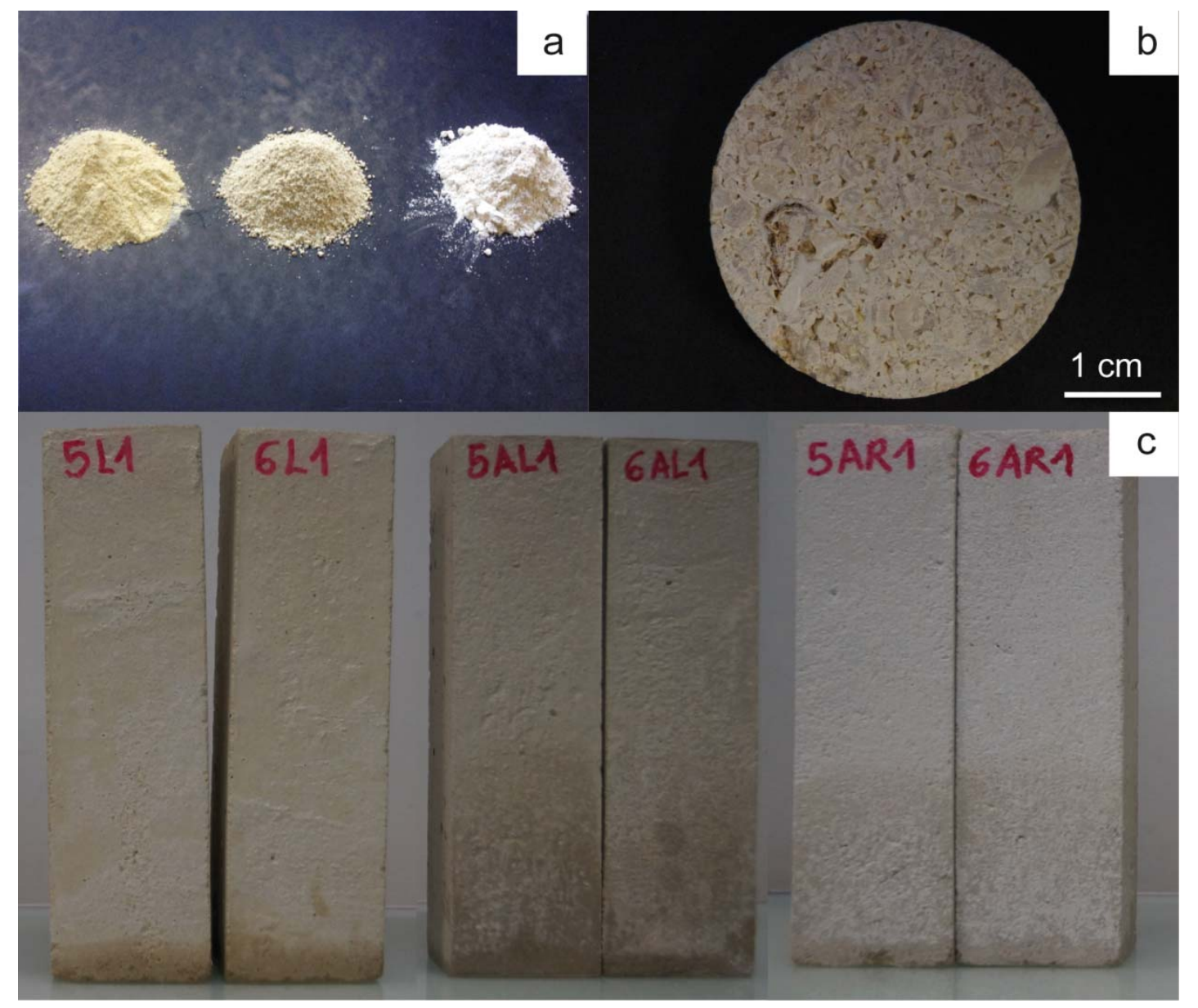


FIGURE 2
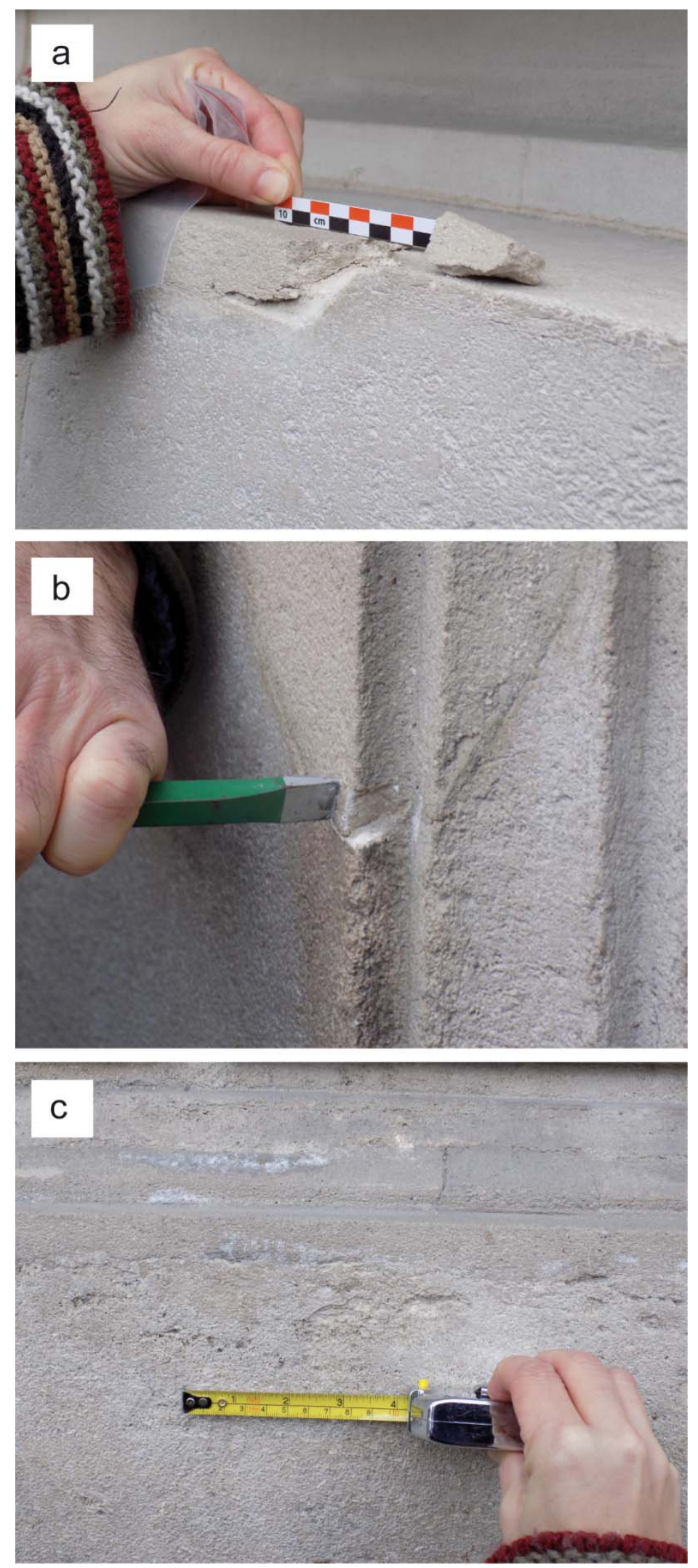


\section{FIGURE 3}

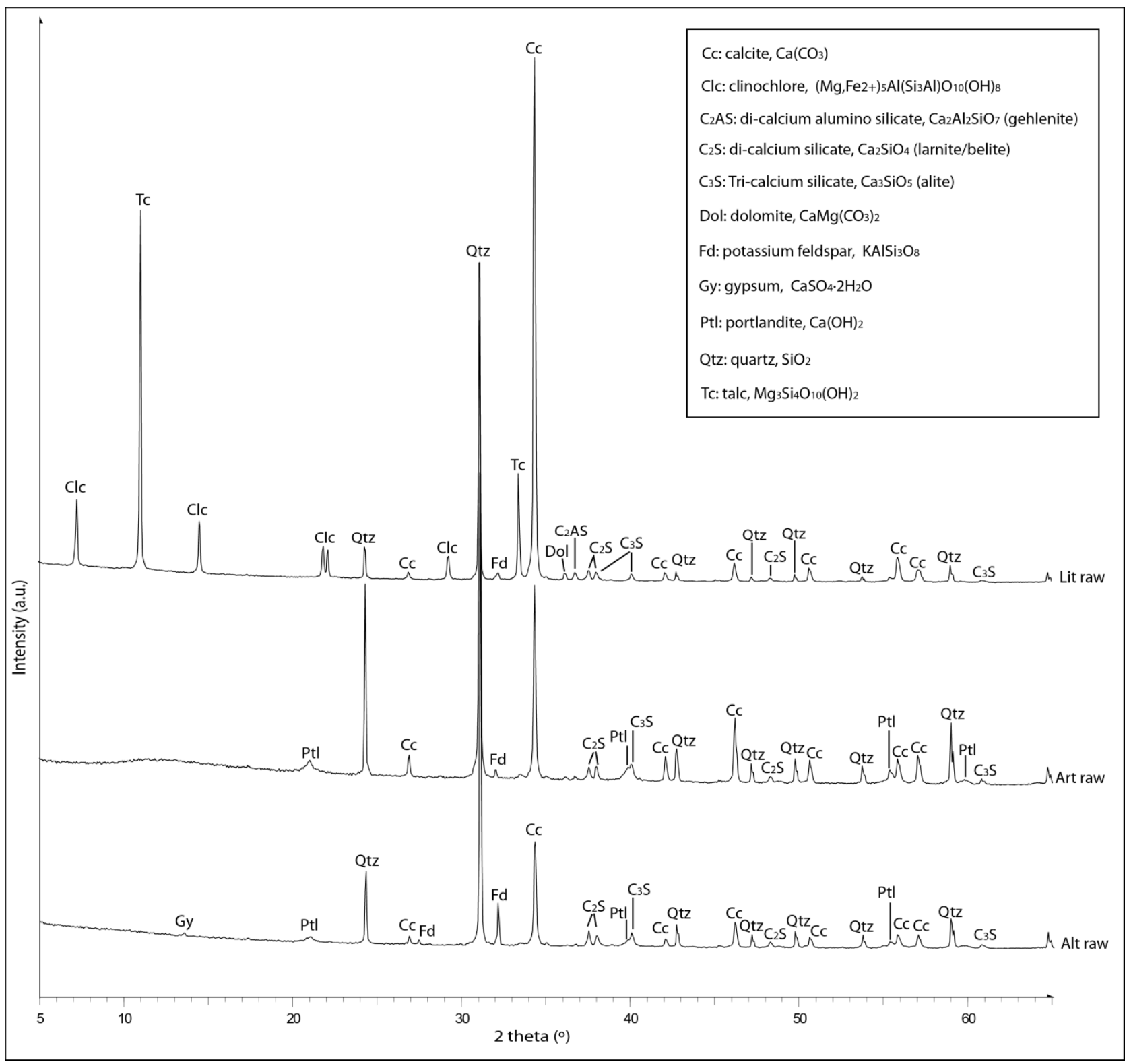




\section{FIGURE 4}

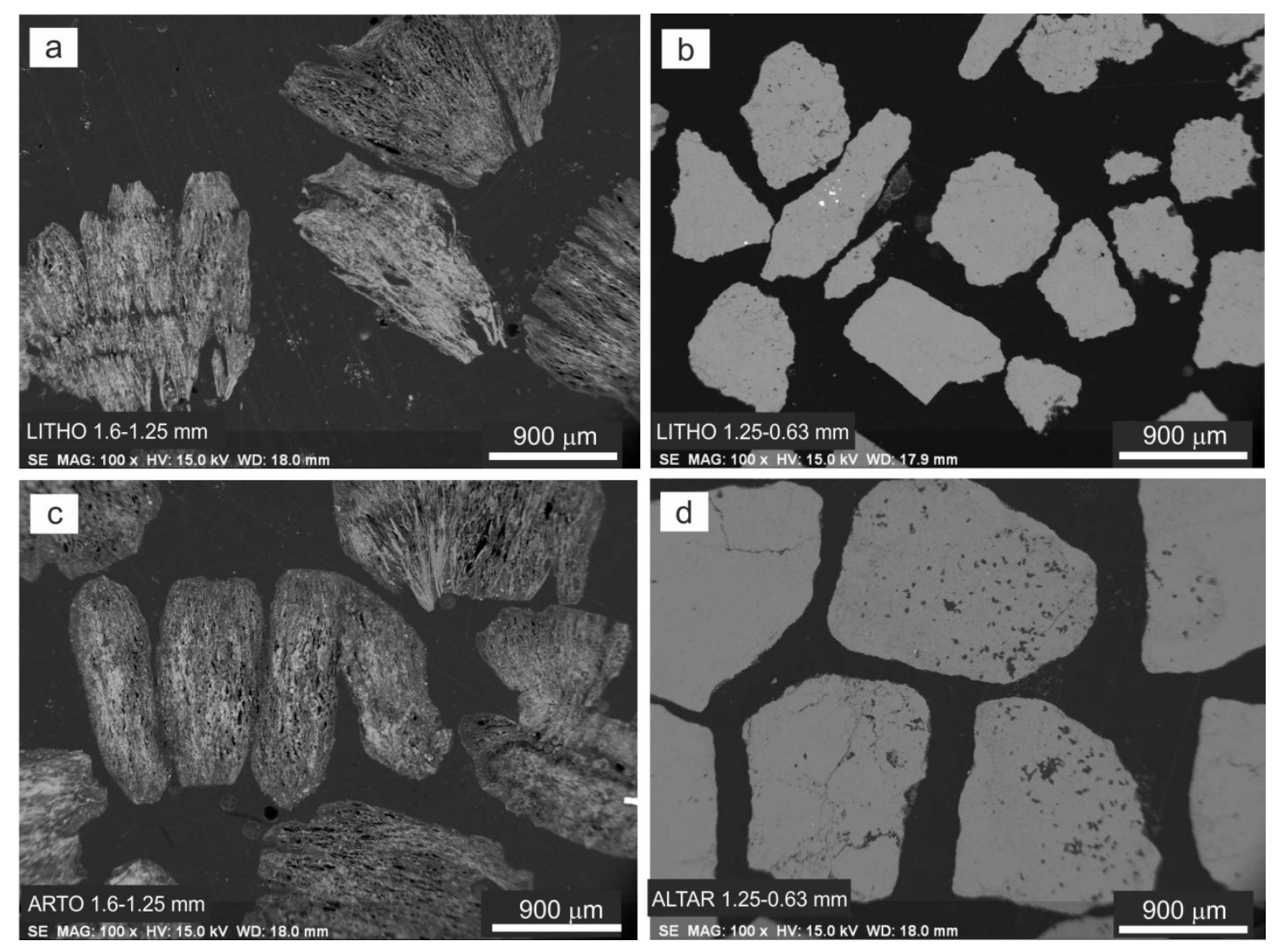




\section{FIGURE 5}
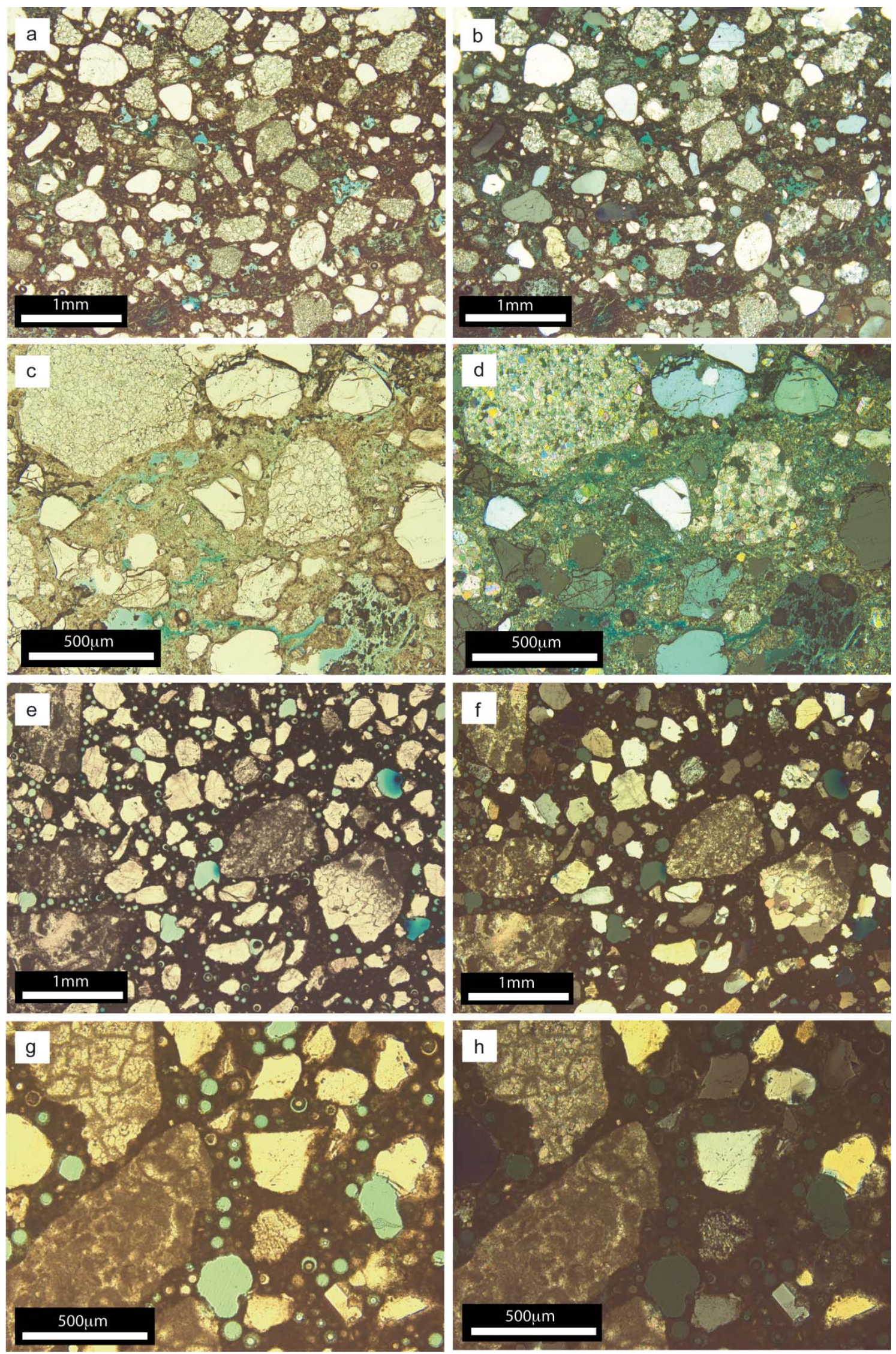


\section{FIGURE 6}

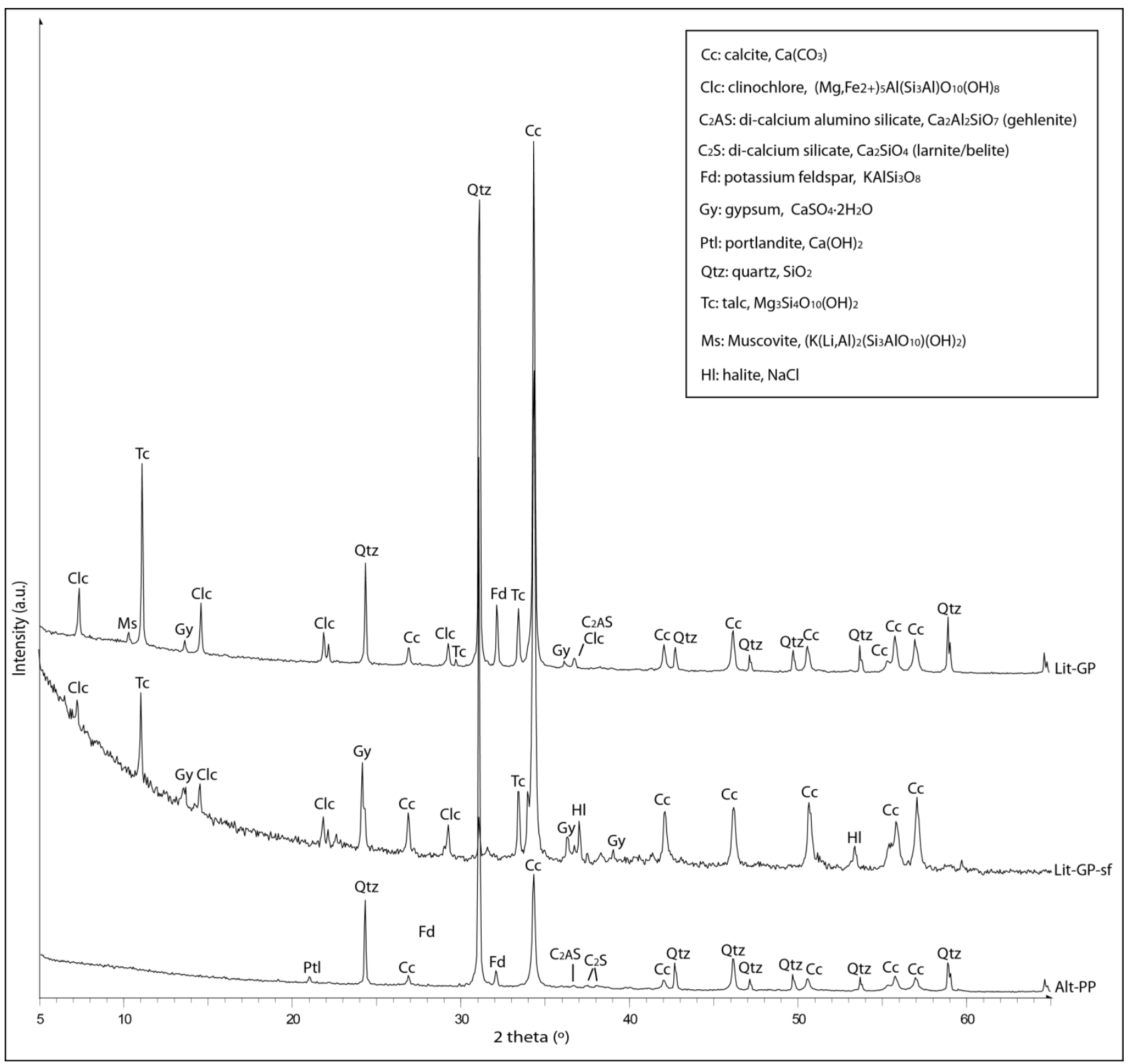




\section{FIGURE 7}
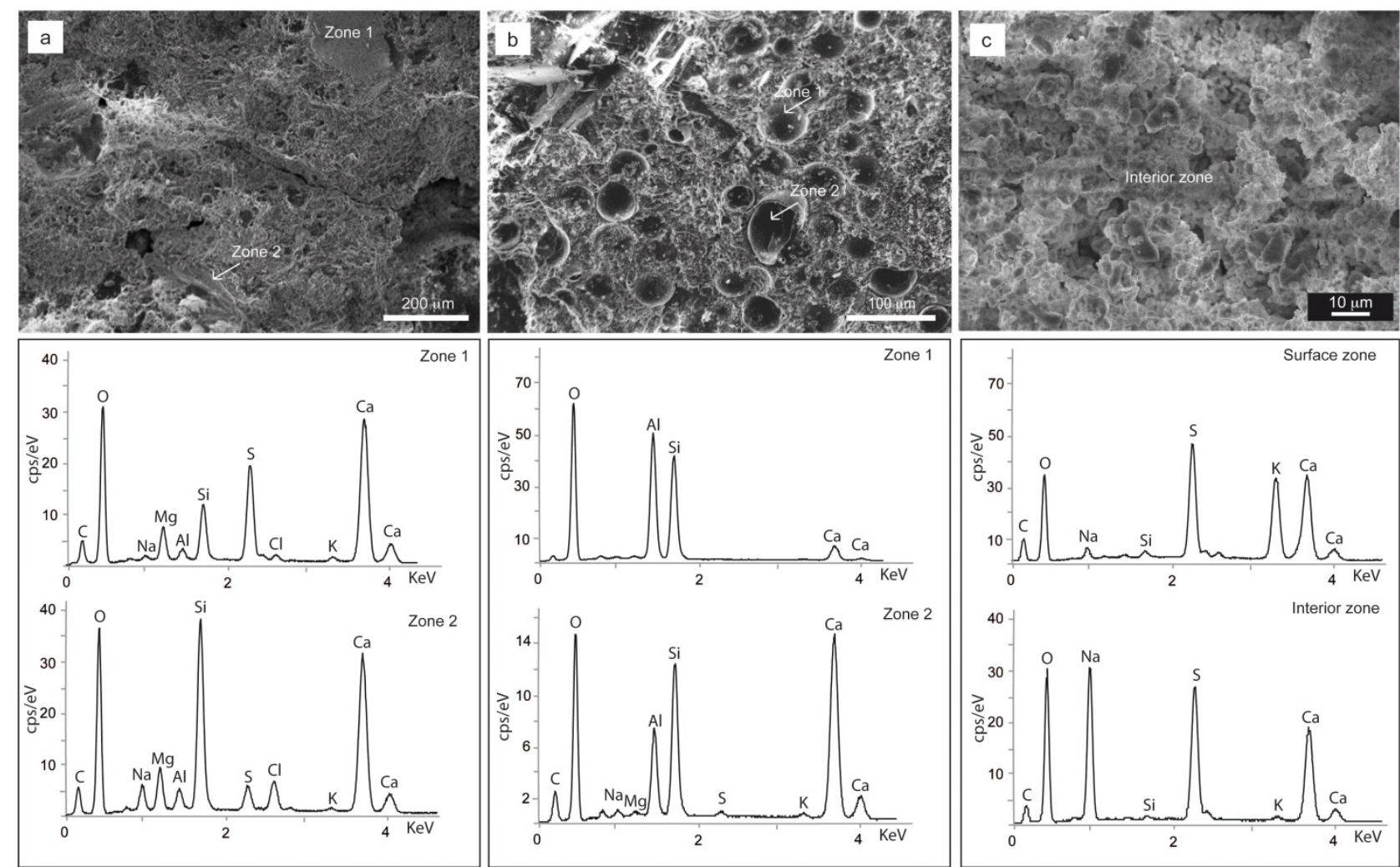

\section{FIGURE 8}

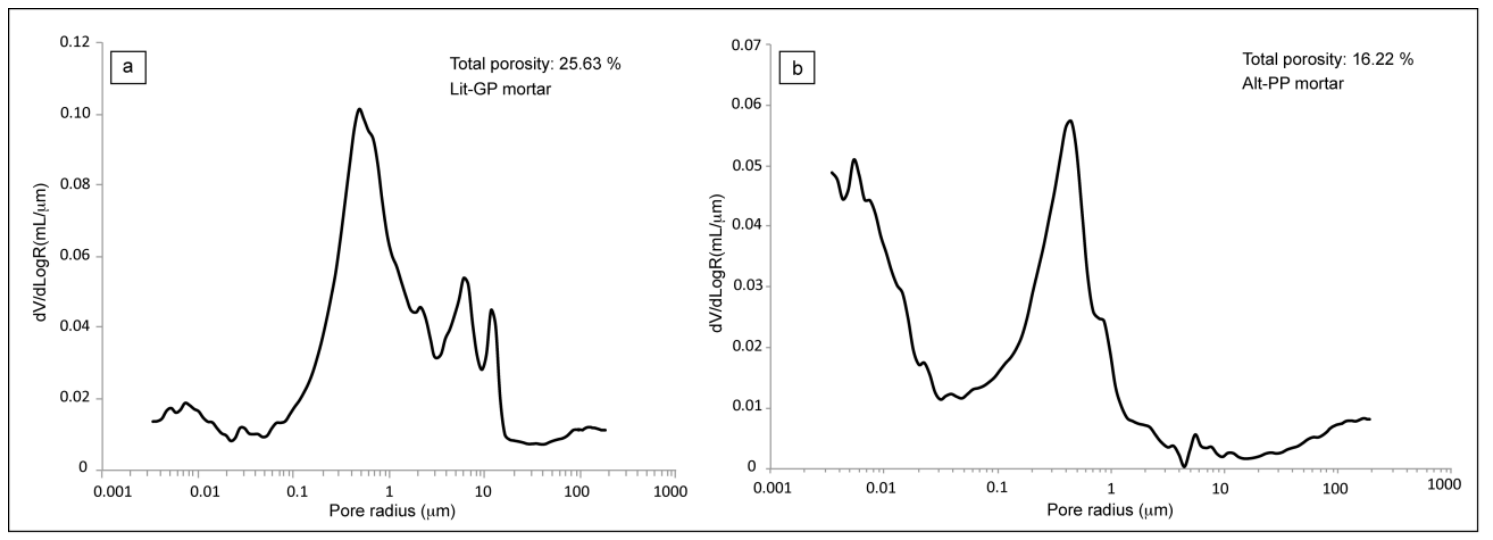




\section{FIGURE 9}
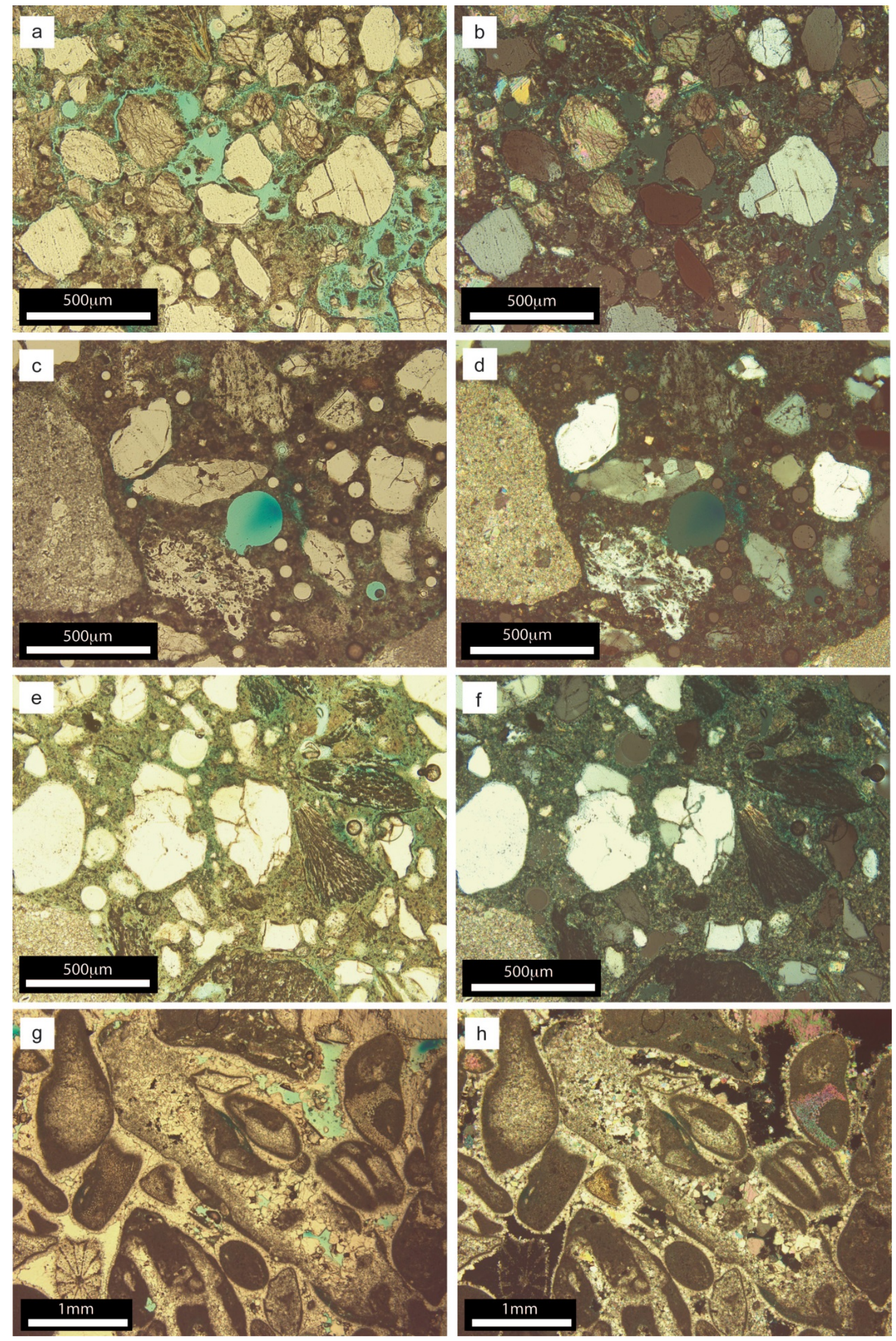


\section{FIGURE 10}

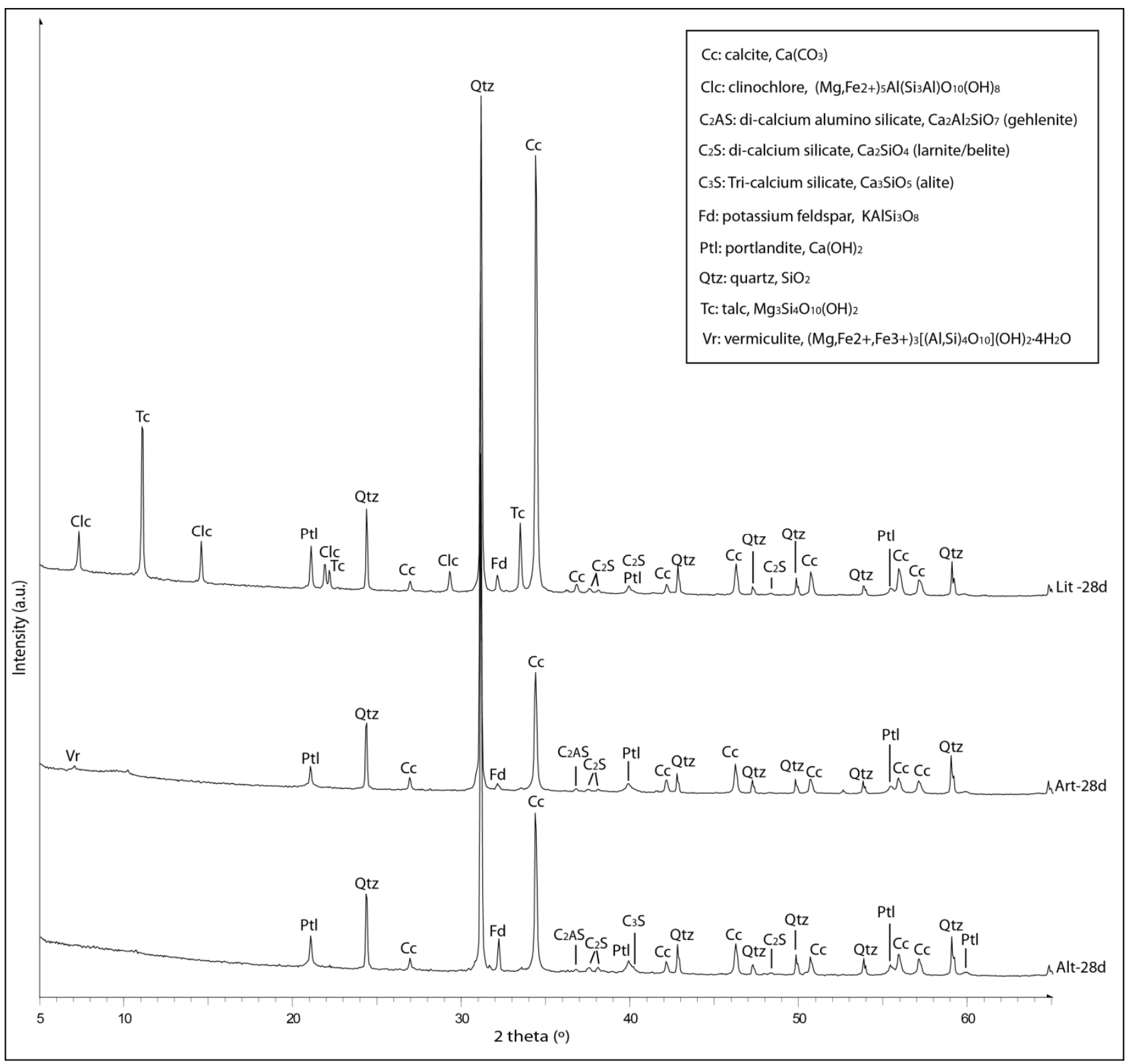




\section{FIGURE 11}
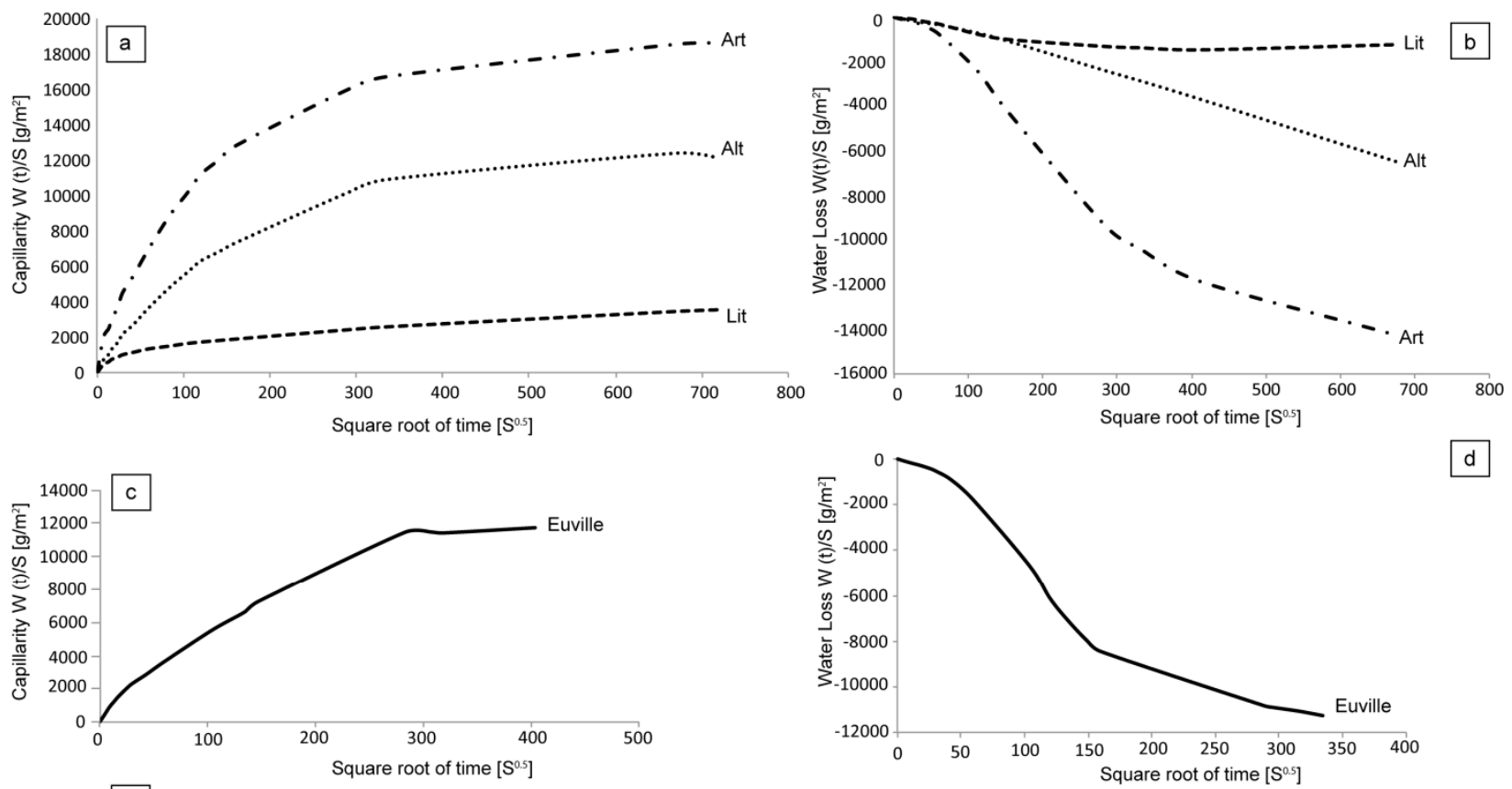

e
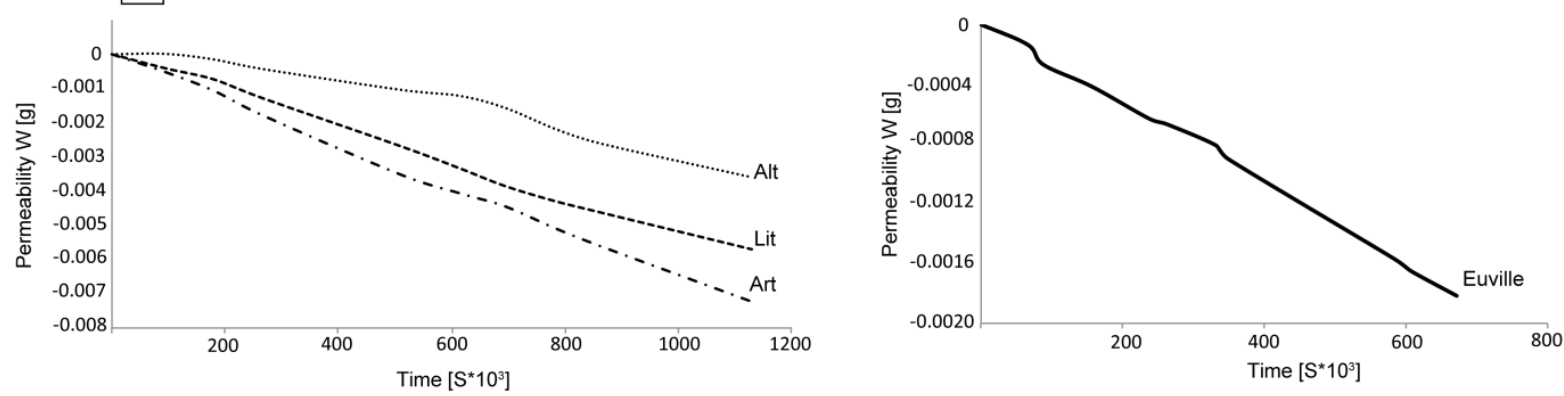
FIGURE 12

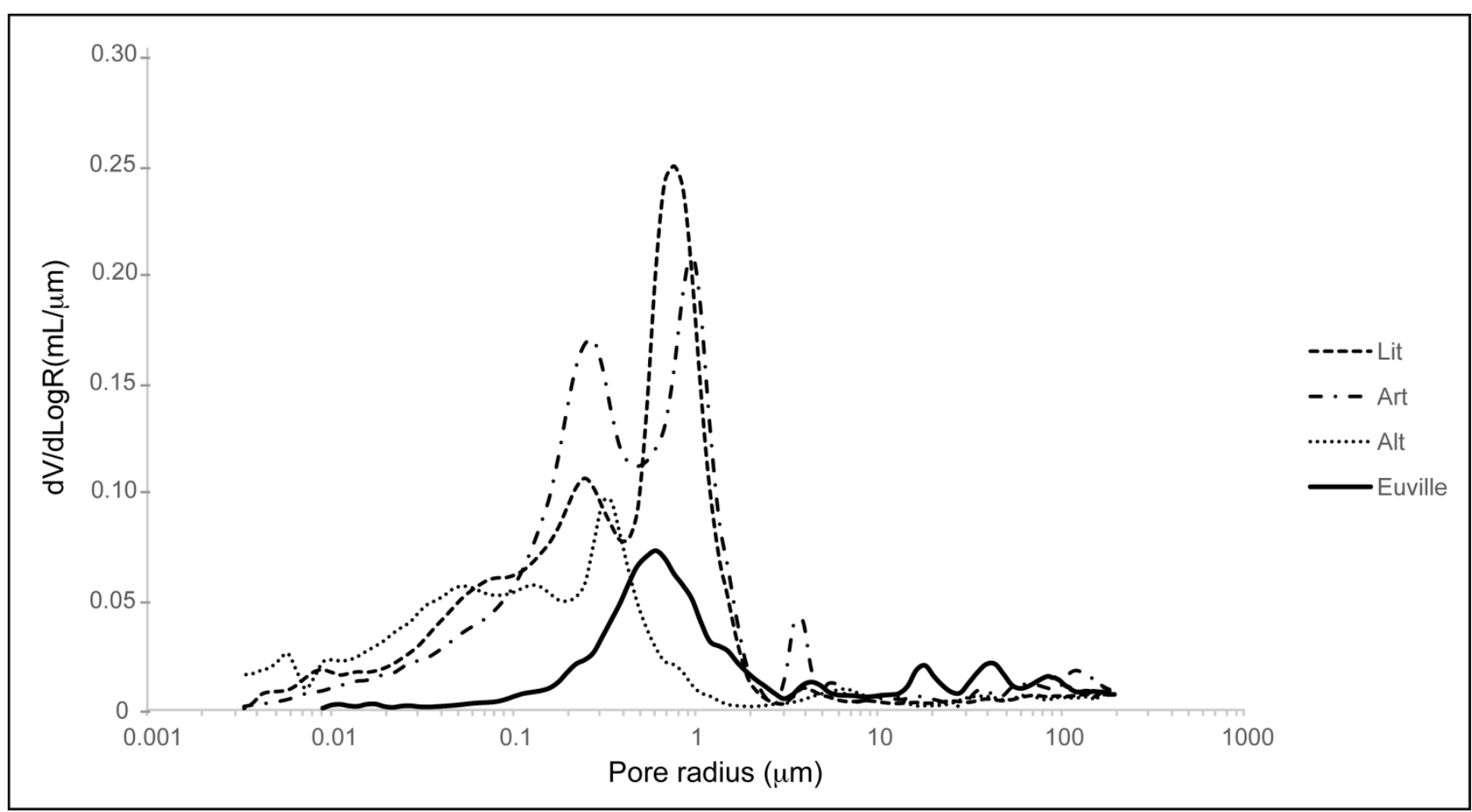

